\title{
Development of fuels and structural materials for fast breeder reactors
}

\author{
BALDEV RAJ, S L MANNAN, P R VASUDEVA RAO and \\ M D MATHEW \\ Indira Gandhi Centre for Atomic Research, Kalpakkam, 603 102, India \\ e-mail: dmg@igcar.ernet.in
}

MS received 22 October 2001; revised 17 May 20002

\begin{abstract}
Fast breeder reactors (FBRs) are destined to play a crucial role in the Indian nuclear power programme in the foreseeable future. FBR technology involves a multi-disciplinary approach to solve the various challenges in the areas of fuel and materials development. Fuels for FBRs have significantly higher concentration of fissile material than in thermal reactors, with a matching increase in burn-up. The design of the fuel is an important aspect which has to be optimised for efficient, economic and safe production of power. FBR components operate under hostile and demanding environment of high neutron flux, liquid sodium coolant and elevated temperatures. Resistance to void swelling, irradiation creep, and irradiation embrittlement are therefore major considerations in the choice of materials for the core components. Structural and steam generator materials should have good resistance to creep, low cycle fatigue, creep-fatigue interaction and sodium corrosion.

The development of carbide fuel and structural materials for the Fast Breeder Test Reactor at Kalpakkam was a great technological challenge. At the Indira Gandhi Centre for Atomic Research (IGCAR), advanced research facilities have been established, and extensive studies have been carried out in the areas of fuel and materials development. This has laid the foundation for the design and development of a 500 MWe Prototype Fast Breeder Reactor. Highlights of some of these studies are discussed in this paper in the context of our mission to develop and deploy FBR technology for the energy security of India in the $21^{\text {st }}$ century.
\end{abstract}

Keywords. Fast breeder reactor; plutonium carbide; mixed oxide; void swelling; mechanical properties; corrosion.

\section{Introduction}

The Indian nuclear power programme has been envisaged to grow in three different phases. Under the first phase of the programme, a series of pressurised heavy water reactors (PHWRs) with natural uranium (U) oxide as the fuel, have been set up. The once-through open fuel cycle, with spent fuel treated as nuclear waste cannot sustain nuclear power development over 
a long term, and so closing the nuclear fuel cycle is the strategy of the Department of Atomic Energy. Therefore, the plutonium $(\mathrm{Pu})$ produced in PHWRs is reprocessed and can be used as MOX (mixed oxides of uranium and plutonium) fuel in thermal reactors. However, this will not be able to grow the nuclear capacity to desired levels. Hence, in the second stage of the programme, the plutonium will be used in fast breeder reactors to grow the nuclear capacity to desired levels. On account of India's large thorium (Th) resources, by use of U-233 based fuels in FBRs and advanced heavy water reactors (AHWRs), we could sustain energy production for longer time durations. Hence, the third phase of the nuclear power programme will involve breeder reactors based on the thorium-U-233 fuel cycle.

The Indira Gandhi Centre for Atomic Research (IGCAR) has been established with the mandate to develop fast reactor technology so that FBRs can be deployed for generating electricity in the decades to come. As part of this strategy, a 40-MW(th) test reactor, the Fast Breeder Test Reactor (FBTR), was constructed and commissioned in 1985. Though the design of FBTR was primarily obtained from France, the construction was essentially an indigenous effort including the fuel, the sodium coolant and the components. Experience with the unique and new carbide fuel and sodium systems including the steam generator has been very good. This test reactor has been utilised for fuel development, reactor physics experiments and irradiation of structural materials. This coupled with the extensive R\&D efforts in all aspects of FBR technology has laid the foundation for the design and development of a 500-MWe Prototype Fast Breeder Reactor (PFBR). Construction of the PFBR is scheduled to start sometime during 2003. PFBR will be the forerunner of a series of FBRs that are to follow soon.

The various research activities at IGCAR are oriented towards solving the complex technological challenges in the FBR fuel cycle. Various R\&D activities related to fuels and materials for FBTR as well as the issues related to the design and development of PFBR form the basis of this paper. Some of the work in the area of fuel development has been carried out in collaboration with the Bhabha Atomic Research Centre (BARC). Development work related to the finalisation of a flow sheet for fabrication of FBTR fuel with stringent specifications was carried out at BARC and the fuel has been fabricated and assembled in the form of fuel pins. The Nuclear Fuel Complex (NFC) has made significant contributions towards fabrication of fuel subassemblies and development of in-core structural materials. Fuel development and fabrication of PFBR subassemblies is a joint collaborative effort between IGCAR, BARC and NFC. A brief description of PFBR system components (Bhoje 2000) is first given below before discussing $R \& D$ achievements in the areas of fuel and materials development.

\section{Prototype fast breeder reactor}

\subsection{Reactor assembly}

PFBR is a sodium-cooled reactor of pool-type design. The core of the reactor consists of fuel subassemblies containing $(\mathrm{U}, \mathrm{Pu})$ mixed oxide fuel, which are immersed in a pool of liquid sodium. The heat transport system consists of a primary sodium circuit, secondary sodium circuit and steam-water system. The flow sheet of the heat transport system is shown in figure 1 . The reactor assembly consists of core, grid plate, core support structure, main vessel, safety vessel, top shields and absorber rod drive mechanism. The minimum sodium temperature in the primary pool of PFBR during normal operation (core inlet temperature) is about $670 \mathrm{~K}$. The mean above-core temperature (core outlet temperature) is about $820 \mathrm{~K}$ during operation, and $923 \mathrm{~K}$ under plant transient conditions (arising due to failure of pumps, rupture of pump 


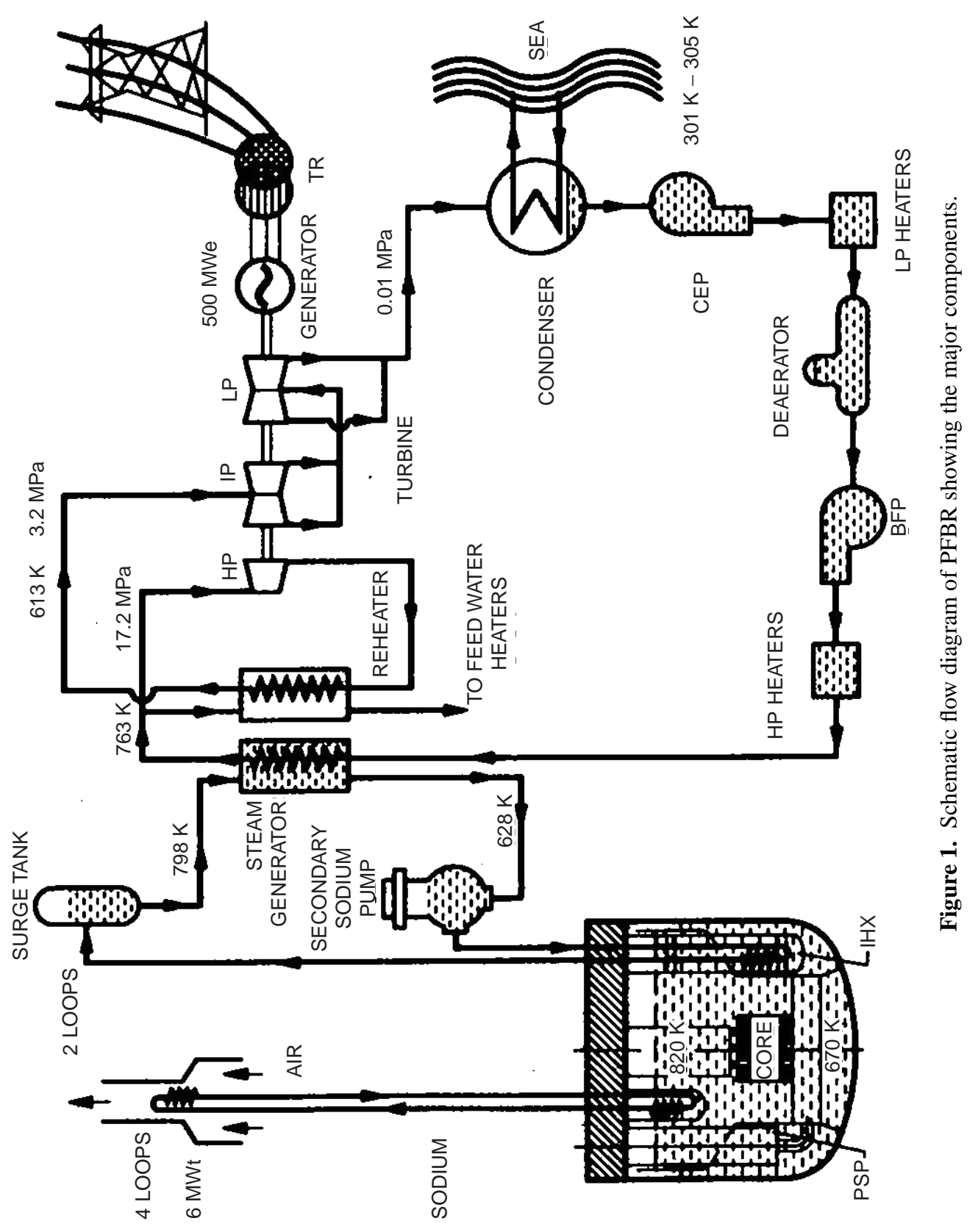


to grid plate pipe, uncontrolled withdrawal of control rod etc.). The environment of operation is liquid sodium or argon with sodium vapour or nitrogen gas depending upon the location of the component. Except for the components near the core like grid plate, which may see a fast fluence of $10^{21}$ to $10^{22} \mathrm{n} \mathrm{cm}^{-2} \mathrm{~s}^{-1}$, for all other components such as inner vessel, main vessel, safety vessel, intermediate heat exchanger and pumps, radiation is not a consideration. Structural materials chosen for sodium circuit components must possess adequate high temperature mechanical properties such as creep, low cycle fatigue and creep-fatigue interaction, and should be compatible with liquid sodium coolant. The primary stresses are low in the primary sodium circuit. However, secondary stresses of thermal origin are quite significant. These stresses are both steady and transient in nature (Chetal et al 1992). The life of components operating at temperatures $>670 \mathrm{~K}$ is determined by creep and fatigue damage. The design life of the structural components is 40 years.

\subsection{Fuel subassembly}

Successful operation of FBRs is largely dependent on the performance of core structural materials, i.e. clad and wrapper materials of the fuel subassembly, which are subjected to intense neutron irradiation. The neutron flux levels in FBRs $\left(\sim 10^{15} \mathrm{n} / \mathrm{cm}^{2} \mathrm{~s}^{-1}\right)$ are about two orders of magnitude higher as compared to thermal reactors. This leads to unique materials problems like void swelling, irradiation creep and helium embrittlement. In PFBR, the fuel clad tubes will experience temperatures in the range of 673-973 K under steady-state operating conditions. Under transient conditions temperatures can rise up to $1273 \mathrm{~K}$. For the initial target burn-up of 100,000 MWd/t (megawatt day per tonne), the maximum neutron dose is $85 \mathrm{dpa}$ (displacements per atom, i.e. average number of times that an individual atom is displaced from its lattice site). Major loads experienced by the fuel clad are the internal pressure due to accumulated fission gases released from fuel matrix $(\approx 5 \mathrm{MPa})$ and moderate fuel-clad interaction. The latter occurs especially during transient over-power (TOP) incidents. The wrapper tubes of the core subassembly operate at relatively lower temperatures than the fuel clad. The typical operating temperature range is $673-873 \mathrm{~K}$ which incidentally falls within the peak swelling temperature range for austenitic SS. The temperature may rise up to $1073 \mathrm{~K}$ during transients. The peak neutron dose is about 85 dpa similar to that for fuel clad. Major loads on the wrapper tube are the internal pressure due to sodium coolant $(\sim 0.6 \mathrm{MPa})$ and the interaction loads at the contact pads due to bowing of the subassemblies under temperature and swelling gradients. Fuel clad and wrapper materials should therefore be resistant to irradiation-induced swelling and embrittlement, sodium corrosion, and meet adequate endof-life creep strength and ductility. For economic viability, the target burn-ups required for FBRs are high, more than 200,000 MWd/t. The achievable fuel burn-up is limited by the void swelling of the wrapper material. A schematic diagram of the PFBR fuel subassembly and fuel pin are shown in figure 2 .

\subsection{Steam generator}

Steam generators in sodium-cooled fast reactors employ a single wall separating the water/steam from the sodium. The very high reactivity of sodium with water makes the steam generator a critical component in determining the efficient running of the plant and demands high integrity of steam generator components in case of a leak leading to sodium-watersteam reaction. The high integrity of these components can be achieved by choosing a proper material followed by optimised design and fabrication. Material for FBR steam generator applications should have good high temperature mechanical properties, including creep and 
low cycle fatigue. In the case of the PFBR steam generator, the sodium inlet temperature is $798 \mathrm{~K}$ whereas the steam outlet temperature is $766 \mathrm{~K}$. Resistance to loss of carbon to liquid sodium and consequent reduction in strength, resistance to wastage in case of small leaks leading to sodium-water reaction, and resistance to stress corrosion cracking in sodium (caustic) and water (chloride) media are other important considerations in the choice of the material for the steam generator.

\section{FBR fuels}

The design of the nuclear fuel is an important aspect which has to be optimised for efficient, economic and safe production of power. The fuel used in a nuclear reactor is in the form of bundles, each consisting of a number of pins. The fuel used in fast reactors has to have a higher enrichment of fissile content than the thermal reactor fuels, because of the lower cross section of fission reaction with fast neutrons as compared to thermal neutrons. In addition, in a reactor with a relatively small core (like FBTR), the fissile content has to be still higher to account for higher rate of loss of neutrons from the small core. The fissile enrichment is usually provided in the form of plutonium $(\mathrm{Pu})$. For the first core (Mark I) of FBTR, therefore a $\mathrm{Pu} /(\mathrm{U}+\mathrm{Pu})$ ratio of 0.7 was required in the fuel. For the Mark II expanded core, the $\mathrm{Pu} /(\mathrm{U}+\mathrm{Pu})$ ratio is 0.55 ; for a large reactor such as the prototype fast breeder reactor (PFBR), the $\mathrm{Pu} /(\mathrm{U}+\mathrm{Pu})$ ratio in the fuel is only around 0.25 . Thus, the fast reactor programme in India has had to deal with a variety of fuels with differing fissile contents.

To be used as a nuclear fuel, a material has to satisfy many important criteria. It should be thermodynamically stable over a wide temperature range. There should be preferably no phase change in the operating temperature range of the reactor. The fuel should have a high melting point, good thermal conductivity, compatibility with the coolant material, and be easy to fabricate and reprocess.

The most important form of fuels which meets these requirements is the oxide- $(\mathrm{U}, \mathrm{Pu}) \mathrm{O}_{2}$ a solid solution of uranium and plutonium oxide-has been routinely irradiated to burn-up levels of 15 atom $\%$ or more $(1$ atom $\%=8,800 \mathrm{MWd} / \mathrm{t}$ ), with very low failure rates (less than $0.01 \%$ ). For FBTR, therefore, a uranium-plutonium mixed oxide fuel was the first choice. However, the use of mixed oxide fuel with $\mathrm{Pu} /(\mathrm{U}+\mathrm{Pu})$ ratio of 0.7 was ruled out on technological considerations. The possibility of using a plutonium-uranium mixed oxide fuel with $\mathrm{Pu} /(\mathrm{U}+\mathrm{Pu})$ of 0.3 , and the uranium enriched to about $85 \%$, was therefore investigated. However, difficulties were experienced in obtaining enriched uranium for the fuel. Hence, the choice had to be made from a fuel belonging to the category of carbide, nitride or alloys. These fuel forms have the advantages of high metal atom density and high thermal conductivity, as well as high breeding ratio. However, experience with these fuels, especially as a driver fuel for reactors, has been very limited. We had to opt for the use of carbide because of the relatively higher level of experience available on the in-reactor performance of this fuel as compared to other forms. It was thus decided that uranium-plutonium mixed carbide would be used as the fuel for FBTR.

\section{4. $R \& D$ activities in support of the fuel cycle}

\subsection{Fuel design}

A number of physicochemical and thermomechanical data are required for the design of a nuclear fuel element. The melting point and the thermal conductivity of the fuel determine the 
power that can be tapped from the fuel. The thermal conductivity also influences the restructuring and transport processes inside the fuel material, as these depend upon the temperature gradients inside the fuel pellet. Since these data were not available for the carbide fuel chosen for FBTR, they had to be generated in-house in order to optimise the fuel design as well as to give us confidence in the performance of the fuel. Data on the melting point of the carbide fuel were generated at BARC. Thermal conductivity of the fuel was determined from the thermal diffusivity of the fuel, which was measured at BARC as well as at IGCAR, by a technique employing the laser-flash method (Sengupta et al 1986; Krishnaiah M V, Sreenivasan G and Srirama Murthy P, unpublished work). Excellent agreement was obtained between the data measured in the two different laboratories on air-sensitive and radioactive samples.

To ensure that the fuel can be subjected to the desired linear heat ratings without the centreline temperature of the fuel crossing the melting point, a unique out-of-pile simulation facility was set up, in which the thermal behaviour of the fuel in the reactor was simulated by electrical heating of a fuel column with simultaneous removal of heat from its surface by flowing helium (Antony et al 1997). These studies convinced the safety authorities that the FBTR carbide fuel pin could be operated safely at a linear power rating of $\approx 350 \mathrm{~W} / \mathrm{cm}$ without any fear of centreline melting.

To evaluate the possibility of carburisation of the stainless steel cladding by chemical interaction with the fuel, it is necessary to have information on the carbon potentials of the carbide fuel as well as the clad material at various temperatures. At IGCAR, the carbon potential of the (U,Pu) mixed carbide fuel corresponding to Mark I as well as Mark II compositions have been measured at temperature ranges typical of the fuel-clad interface (Rajendran Pillai et al 1989; Anthonysamy et al 1995) employing the methane hydrogen equilibration technique. Measurements were also carried out at BARC using the isopiestic technique (Garg et al 1986). The results of these studies indicated that the carbide fuel of the chosen compositions does not lead to any significant carburisation of the stainless steel cladding chosen for FBTR. In addition to the above, extensive experimental investigations as well as modelling activities were carried out at BARC and IGCAR to provide a thorough understanding of the chemistry of the carbide fuel and its thermo-mechanical behaviour.

The chemistry of the carbide fuel also dictated that we had to have stringent control of the carbon stoichiometry in the fuel. The metal phase is undesirable in a carbide fuel, since it is $\mathrm{Pu}$-rich, melts at the operating temperatures, attacks the cladding etc. Since the carbon/metal (C/M) ratio decreases with burn-up, to ensure that the metal phase does not form during irradiation, the fuel is fabricated as a monocarbide with 5 to 15 volume $\%$ of sesquicarbide. The presence of oxygen in the fuel has to be especially controlled since this increases the carbon potential of the fuel, and also facilitates transport of the carbon to the cladding through formation of carbon monoxide.

The carbide is known to be a pyrophoric material. Therefore, preparing the carbide and fabricating it in the form of pellets has to be done in high purity inert atmosphere glove boxes to avoid any possibility of oxidation that can lead to fire. The entire charge of carbide fuel for the core of FBTR was fabricated in BARC and this has provided valuable experience in the fabrication of carbide fuels (Ganguly et al 1986). It is a matter of great pride that the carbide fuel developed in our country meets all the specifications. The satisfactory performance of the fuel in the reactor has been confirmed by post-irradiation examination (PIE). For carrying out PIE, state-of-art facilities have been set up at IGCAR. These consist of hot cells which are designed to handle irradiated fuels and materials, which emit $\alpha, \beta$ and $\gamma$ radiation under an inert atmosphere. The hot cells are equipped with state-of-art metallurgical and radiochemical equipment covering a wide spectrum of non-destructive as well as destructive techniques, 


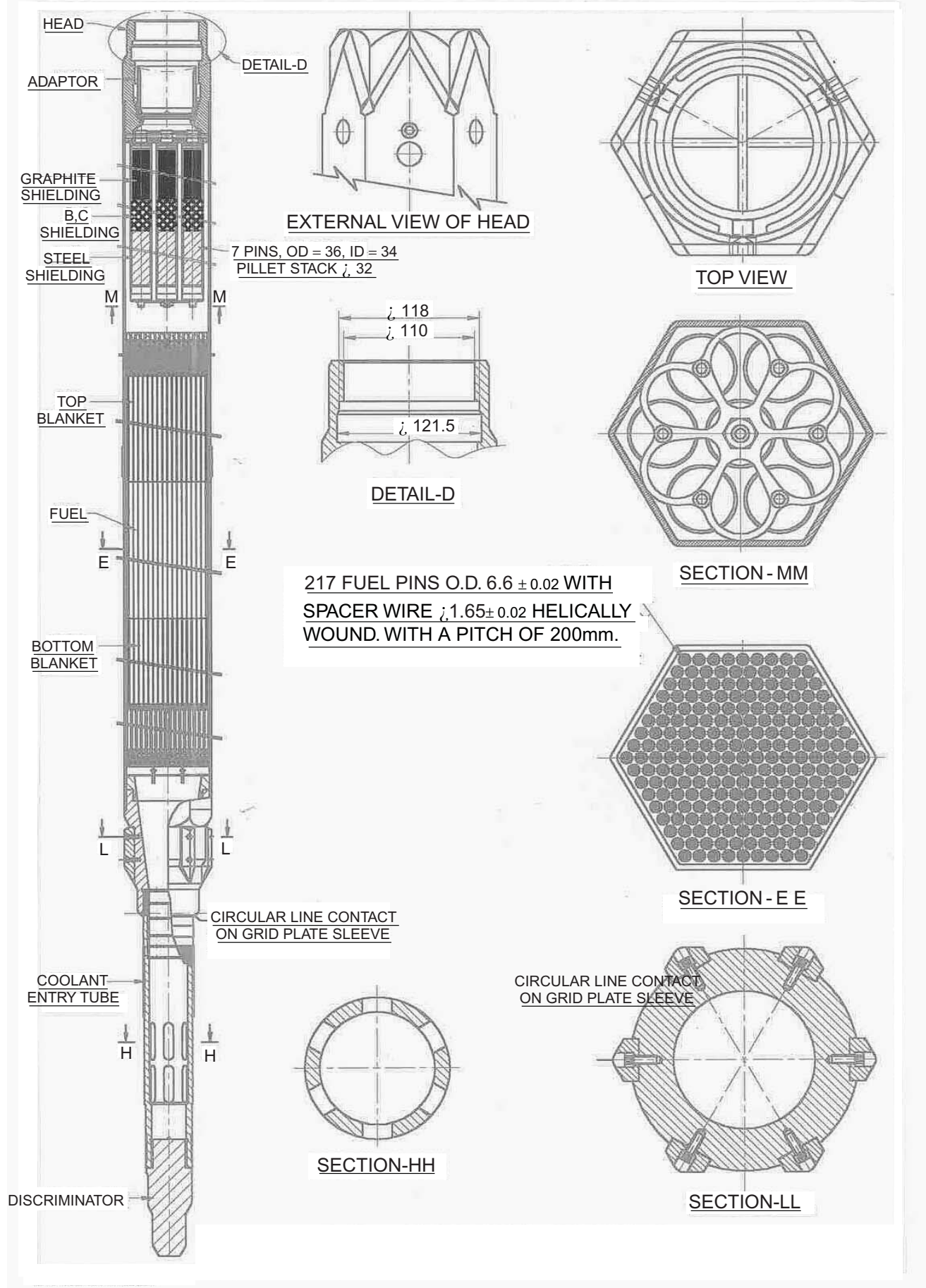

Figure 2. Fuel subassembly. 


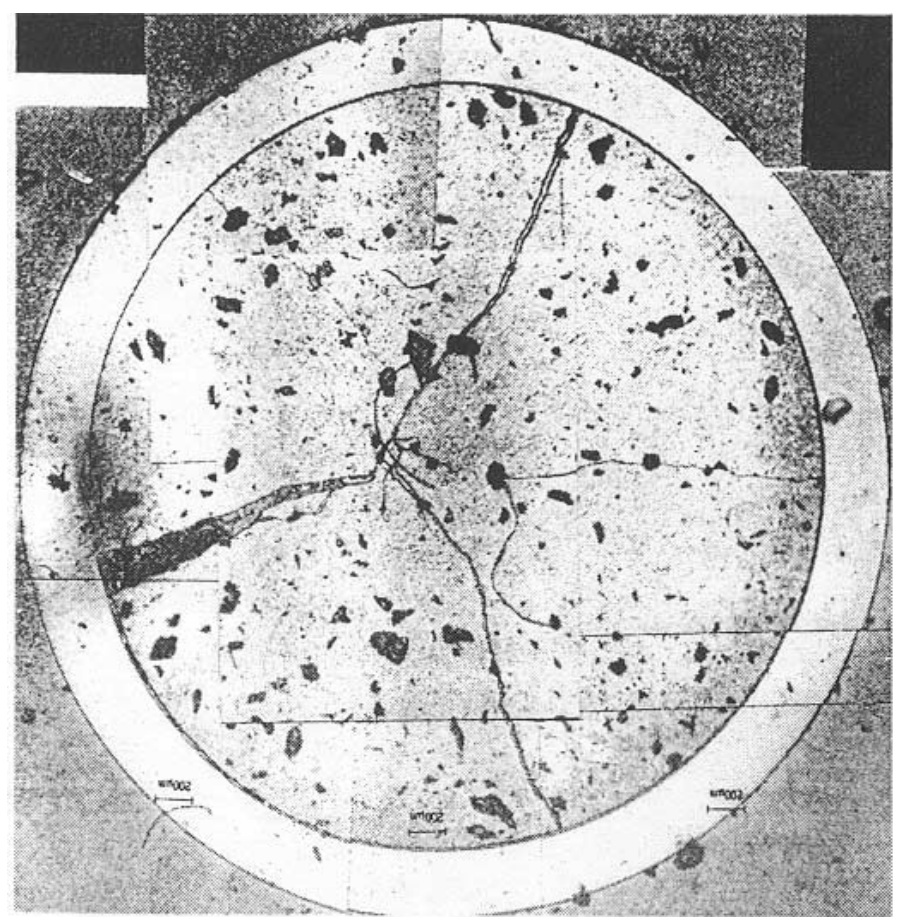

Figure 3. Cross-section of the FBTR fuel pin after burn-up of 50,000 MWd/t. The fuel is decorated with radial cracks emanating from the centre of the fuel pellet.

consisting of dimensional measurements, leak testing, $X$-radiography, eddy current testing, measurement of mechanical properties such as tensile strength on miniature test specimens, burn-up measurements, fission gas analysis etc.

On completing 25,000 MWd/t burn-up, detailed post-irradiation examination was carried out on one of the FBTR fuel subassemblies. Based on the excellent fuel performance confirmed from these investigations, it was decided to extend the life of the fuel and carry out further investigations after 50,000 MWd/t burn-up. One subassembly, discharged from the FBTR core after a burn-up of approximately $50,000 \mathrm{MWd} / \mathrm{t}$, has been examined. The results of the visual examination as well as various measurements such as dimensional measurements of the subassembly, eddy current testing and $X$-radiography revealed that the fuel has performed very well in the reactor. There was no significant change from the original dimensional tolerances. No appreciable corrosion has taken place on the clad in spite of continuous exposure to liquid sodium for nearly 16 years. There was no indication of fuel-clad mechanical interaction. Figure 3 shows a cross-section of the fuel pin. The radial cracks in the pellets and the fuel-clad gap still available in the fuel pins indicated that further swelling of the fuel could be accommodated before initiation of fuel-clad mechanical interaction. In fact, the fuel has crossed a burn-up of $100,000 \mathrm{Mw} d / t$ recently and we now have the confidence that the fuel would reach still higher levels of burn-up, say 150,000 MWd/t.

\subsection{Thermophysical and thermochemical properties}

The need for knowledge of the thermophysical and thermochemical properties of the fuel was emphasized earlier. Similar investigations are called for with regard to a host of other 
materials including fission product compounds likely to form in the fuel during irradiation, materials that could form matrices for immobilising the nuclear waste, materials for control rod applications, etc. At IGCAR, a number of experimental facilities have been set up, and a variety of techniques employed, for such studies. A few of the facilities, not mentioned earlier in the text, but of immense value to FBR development, are outlined below.

A Laser Vaporization Mass Spectrometry (LIV-MS) facility has been developed in-house to generate vapour pressure data on nuclear fuel materials at very high temperatures (2500$5000 \mathrm{~K}$ ), required to analyse accident conditions (Joseph \& Sivakumar 1998). This is the first LIV-MS facility of its kind in our country. The facility has been used to study the vapor species and their pressures over $\mathrm{UO}_{2}$ (Joseph et al 1997), UC and $\mathrm{ThO}_{2}$ (Joseph et al 2002). It is planned to carry out measurements over $(\mathrm{U}, \mathrm{Pu})$ carbide materials after incorporating the vaporization chamber in a glove box. Laser ablation of a sample of the fuel material, followed by matrix isolation infrared spectroscopy is a new approach being explored for obtaining thermodynamic information on fuel materials. The surface chemistry of air-exposed carbide samples is being studied employing $X$-ray photo spectroscopy and secondary ion mass spectrometry (Asuvatharaman et al 1995). The gas equilibration technique, employed for measuring the carbon potential over the mixed carbide fuel, has also been subsequently extended to other carbide systems involving fission product and clad constituents such as UMO-C system and Cr-C system (Ananthasivan et al 1993; 1996, 1997; Anthonysamy et al 1996).

It is well-known that oxidation of the stainless steel clad, by the oxide fuel, is considerably influenced by the presence of the fission products, especially, cesium, iodine and tellurium, at the fuel-clad interface (Adamson et al 1985). The thermodynamic properties as well as phase relations of the tellurium compounds of the clad components have been investigated in great detail, employing high temperature mass spectrometry (Saha et al 1988; Viswanathan et al 1989; Sai Baba et al 1993; Mathews 1996) These studies led to the inference that only a hyper-stoichiometric fuel establishes a tellurium activity that is high enough for the formation of metal tellurides. To study the concentration of the reaction products in the clad as a function of depth from the surface, a glow discharge spectroscopy technique has been developed.

\subsection{Thermochemical modelling}

Measurement of properties of the plutonium containing fuel materials over a wide variety of compositions and temperature range is a stupendous task. Thermochemical modelling is therefore required to supplement the experimental efforts and to generate a more complete picture of the fuel chemistry. At IGCAR, the chemistry of the U-Pu-C-N-O system was modelled in order to arrive at the carbon potentials and vapour pressures as a function of the composition and the effect of impurities such as oxygen and nitrogen on these properties (Anthonysamy et al 1995; Sai Baba et al 1987). The effect of conditions employed during the fuel preparation by carbothermic reduction on the final overall composition of the fuel obtained has also been computed (Anthonysamy 1986; Anthonysamy et al 1989). These computations have helped to a large extent in understanding the influence of various parameters on the fuel properties.

\subsection{Fuel reprocessing}

Recycling of plutonium present in the irradiated fuel with minimum delay is important to ensure rapid growth of fast reactor systems, and to keep the inventory of plutonium to a 
minimum. Thus, fuel reprocessing forms a critical link in the fast reactor fuel cycle. The irradiated fuel discharged from FBTR and PFBR have to be reprocessed with least delay, commensurate with current technological levels. Fast reactor fuels are normally reprocessed by the conventional PUREX process (based on solvent extraction for separating Pu and $\mathrm{U}$ ) on which vast experience exists in our country for thermal reactor fuels. However, the high levels of $\mathrm{Pu}$ and high burn-up of fast reactor fuels introduce a number of challenges in reprocessing. It must also be pointed out that there is practically no plant-scale experience the world over on the reprocessing of carbide fuels. A comprehensive programme on research and development related to fuel reprocessing has therefore been initiated at IGCAR.

A pilot plant, Lead Mini Cell (LMC), is being commissioned to reprocess the first few cores of FBTR fuel assembly. All the components of LMC have been totally developed and built in-house. Basically the process involves chopping, dissolution, feed clarification, solvent extraction and partitioning. Single pin chopping process has been developed for cutting the fuel into small pieces to increase the rate of dissolution. The dissolution of the carbide fuels in nitric acid leads to the formation of a number of organic compounds. These compounds affect the recovery of plutonium, and also disturb the hydrodynamic performance of the extraction systems. A novel dissolution method, called electro oxidative dissolution technique, has been developed for destroying these organics. For this dissolver, cost effective platinum electroplated anodes have been developed in collaboration with Central Electrochemical Research Institute, Karaikudi. The performance of an alternative electrode developed in-house has also been satisfactory. A titanium electrolytic dissolver has been fabricated and installed for dissolving FBTR fuel. Titanium to stainless steel dissimilar metal-joining process has been established to ensure that the joint is qualified to meet the requirements of both corrosion and mechanical strength. To remove the fines which may be generated during dissolution, a high-speed centrifuge that can be remotely operated and maintained has been developed. The high radiation levels in the solution demand the design and development of short residence time contactors such as centrifugal extractors to minimise the solvent damage. Such contactors have been developed at IGCAR for a wide range of flow rates. Electrolytic in-situ partitioning methods have also been developed to obtain plutonium and uranium in pure form separately. The solvent extraction process has been modelled successfully to analyse the extraction flow sheet.

The LMC plant is designed for remote operation and maintenance. For this purpose, many gadgets such as articulated master slave manipulators, remote samplers etc., have been incorporated in the plant. The operation of LMC will serve to understand process problems, gain operational experience and provide solutions to the prototype plant, Fast Reactor Fuel Reprocessing Plant (FRFRP), under construction.

While reprocessing through the PUREX route will be adopted for the PFBR, it has been recognised that non-aqueous, pyroelectrochemical processes are potential candidates for reprocessing fast reactor fuels with high burn-up after short cooling times. These processes do not use aqueous solutions, therefore, there is little risk of criticality, as a result of which the plant can handle large quantities of fissile material in a small volume. The waste is produced in solid form in a small volume. Recognising these advantages, a programme for establishing the pyrochemical schemes is underway at IGCAR. A lab-scale facility for pyrochemical processing has been established, and the recovery of uranium demonstrated. Based on this experience, studies are being undertaken to develop pyrochemical processes for oxide fuels as well; it is also proposed to undertake scaling-up of the process, to gain experience on large-scale handling of molten salts, and remotisation of the process. 


\subsection{Future activities}

The proposed fuel for PFBR is $(\mathrm{U}, \mathrm{Pu})$ mixed oxide, with $\mathrm{Pu} /(\mathrm{U}+\mathrm{Pu})$ ratio of approx. 0.25 . The oxide is more easy to fabricate and reprocess. The swelling of the oxide fuel is very low compared to advanced fuels such as carbide or metallic fuel. These properties more than make up for its lower breeding ratio and thermal conductivity. Further, extensive international experience on the behaviour of the oxide fuel under steady state as well as accident conditions has provided immense confidence in the choice of this fuel even though we now have rich experience with regard to the mixed carbide fuel. However, even with oxide, there is need for $R \& D$ to generate all the data necessary for the fuel design. Further, indigenous experience has to be gained on various aspects of the fuel cycle such as fuel fabrication and reprocessing.

In years to come, the fast reactor fuel cycle will continue to be an area of intense research and development activity. Investigations on the behaviour of the carbide fuel will continue, in order to explore the burn-up limits to which the fuel could be driven. Fuel design and performance parameters will be fine tuned to achieve higher levels of burn-up. Reprocessing of the fuel discharged from the FBTR has to be carried out.

It is well-recognized that the success of the fast breeder programme lies in reducing the fissile inventory in the fuel cycle. For this, irradiated fuels have to be processed and fabricated after short cooling times. Towards achieving this goal, equipment such as continuous dissolvers and centrifugal extractors, solvent clean-up technologies etc., are being developed at IGCAR. Also, advanced methods of fuel preparation, such as the sol-gel process, and remote fabrication of the fuel are being established. Other areas of emphasis would be reducing high level waste generation, recovery of minor actinides and development of matrices for safe, long-term disposal of nuclear waste. Towards this goal, collaborative programmes have been initiated between IGCAR and BARC to develop process flowsheets for minor actinide recovery and their demonstration in hot cells, as well as development of precursors for waste matrices and demonstration of technology for fixation of high level waste generated during the reprocessing of fast reactor fuel.

Increasing plant life and reliability of equipment and systems are areas which have significant impact on the fuel cycle cost. Towards achieving this, a comprehensive programme is being implemented in the following areas.

- Specification of stainless steel with tight control over trace elements.

- Choice of alternate materials like titanium-tantalum-niobium alloys for selected equipment.

- Implementation of effective quality control procedures during fabrication and installation.

- Development of in-service inspection of critical equipment like dissolver, evaporators and high level liquid waste storage tanks.

Further, while establishing the oxide as fuel for the PFBR, we would endeavour to achieve target burn-ups of 200,000 MWd/t, through the use of advanced clad and wrapper materials, and carry out reprocessing of the fuel with short cooling times. This would reduce the fuel cycle cost and enhance the cost competitiveness of fast reactors.

Simultaneous with the R \& D dealing with the immediate needs of the fast reactor fuel cycle, we shall continue to keep our long-term interests on the advanced fuels alive, since these promise the vital advantage of higher breeding ratio that is essential for a high growth rate of nuclear power in our country. A sustained $R \& D$ programme on the advanced fuels has 
to be pursued to develop economical, safe and reliable fast reactor technology for meeting the energy needs in the coming decades.

\section{Core materials}

The inherent emphasis on neutron economy in PHWRs that use natural uranium oxide fuel, has resulted in the use of zircaloys for fuel cladding tubes, pressure tubes and Calandria tubes. These alloys are employed in light water reactors which use slightly enriched uranium fuel. This enrichment is in terms of higher concentration of U-235 isotope which is only $0.7 \%$ in naturally occurring uranium. However, because of the poor high temperature mechanical properties, particularly creep strength, zirconium alloys are not suitable for FBR applications. The burn-up level required for FBRs to become economically viable is large and this can be achieved only by the availability of materials resistant to void swelling, irradiation creep and irradiation embrittlement, and with high temperature mechanical properties. The cladding tube operates at temperatures in the range of 673-973 K under steady state operating conditions. Under transient conditions, the temperature can rise up to $1273 \mathrm{~K}$. The hexagonal sheath of the core subassembly operates at relatively lower temperatures than the fuel clad. The maximum neutron dose for target burn-up of 100,000 MWd/t is $85 \mathrm{dpa}$ for the fuel clad and hexagonal sheath. Residence time of the fuel subassembly, and hence the achievable fuel burn-up, is limited by the void swelling of the hexagonal wrapper material. Since fuel cycle cost is strongly linked with burn-up, the importance of developing materials resistant to void swelling and irradiation creep cannot be overemphasised.

Type 316 austenitic stainless steel (SS) with about $20 \%$ cold work has been chosen worldwide as a standard cladding and wrapper material for prototype and commercial FBRs. However, it is realised that at the large burn-ups required for economic operation of FBRs, the extent of void swelling in type $316 \mathrm{SS}$ would be high. This has led to the development of titanium modified type 316 SS, known as Alloy D9 (ASTM designation A771/UNS S38660). The incubation dose for swelling increases from around 45 dpa for cold worked 316 SS to well beyond $100 \mathrm{dpa}$ for alloy D9. (The fluence dependence of swelling generally consists of a threshold fluence below which there is no swelling, followed by a region of low swelling transient period and an acceleration to a regime of steady-state swelling.) Chemical composition of alloy D9 is based on considerations of improving swelling resistance and irradiation creep behaviour. The desired composition is achieved by controlled additions of silicon and titanium, lowering the chromium but keeping oxidation resistance satisfactory, and increasing nickel content. Minor alloying elements having strong neutron absorption cross-section and impurities affecting weldability have been kept to a minimum. A small addition of boron is done to improve creep ductility, which is basically low because of cold work and radiation hardening of the steel. Inclusion contents allowed are stringent so as to minimise radiation embrittlement and sodium attack as the cladding tube wall is extremely thin. Dimensional control is stringently maintained as dimensional variation of the tube has a strong effect on tightness of the pin bundle within the wrapper tube and the fuel clad gap that determines the fresh fuel heat rating. Fine grain size is specified to optimise the mechanical properties. A lower limit of grain size is specified from creep considerations. State-ofthe-art non-destructive examination is considered necessary as the clad tube, the first line of defence in radiation containment is a highly stressed component, with a thin wall and low ductility. 


\subsection{Development of alloy $D 9$}

Alloy D9 has been chosen as the reference material for the wrapper and clad tubes for PFBR. A series of melting, casting and processing trials were carried out at IGCAR with a view to standardizing the process parameters and mechanical properties of this material. Tensile and creep properties of different heats of this alloy were studied as a function of titanium to carbon ratio (Ti/C) of 4, 6 and 8 both in the solution annealed and in $20 \%$ prior cold worked (PCW) conditions. Alloy D9 with Ti/C ratio of 6 exhibited the best tensile properties (Venkadesan et al 1992) while a ratio of $\mathrm{Ti} / \mathrm{C}=4$ showed the best creep properties (Latha et al 2000, 2001). Creep strength of alloy D9 clad tubes was significantly higher than that of 316 SS clad tube. The alloy with $\mathrm{Ti} / \mathrm{C}=4$ was also investigated for its high temperature low cycle fatigue (LCF) and creep-fatigue resistance in the solution annealed and $20 \%$ cold worked conditions at 823 and $923 \mathrm{~K}$ (Sandhya et al 2000, 2001). Under continuous cycling conditions, solutionannealed material exhibited cyclic hardening while cold-worked material exhibited cyclic softening. Solution-annealed material exhibited superior LCF resistance compared to the cold worked material. The deformation substructure in solution annealed material consisted of predominantly planar slip bands at $823 \mathrm{~K}$, and cell structures at $923 \mathrm{~K}$. In the cold worked state, the alloy displayed coarse cells and deformation bands at $823 \mathrm{~K}$ while at $923 \mathrm{~K}$, welldeveloped cells and subgrains occurred. In the cold worked state, the alloy also exhibited very fine carbide precipitation in the matrix. Under creep-fatigue conditions, fatigue life of solution annealed material was higher at longer hold times whereas at shorter hold times, cold worked material showed better fatigue life.

As alloy D9 would be used in the cold worked condition for high resistance to void swelling, and also be subjected to prolonged exposure at elevated temperatures, stability of the microstructure has been carefully evaluated at various $\mathrm{Ti} / \mathrm{C}$ ratios as a function of the amount of PCW in the range of 2.5 to $30 \%$ (Vasudevan et al 1996). The optimum level of cold work that would not lead to softening of the material due to recrystallisation was estimated to be $20 \%$ by employing the Larson-Miller parametric approach. Using a thermodynamic model, the amount of primary carbide which remains undissolved after solution annealing treatment, and the secondary $\mathrm{TiC}$ precipitates which form during ageing, were estimated. The amount of primary coarse precipitates increased with an increase in $\mathrm{Ti} / \mathrm{C}$ ratio which facilitated early onset of recrystallisation. Secondary TiC precipitates were finer in the alloy with $\mathrm{Ti} / \mathrm{C}=4$ and this is beneficial to retard recovery and recrystallisation. This composition provided the best resistance against recrystallisation of the cold-worked structure and hence also the highest creep strength.

Alloy D9 and its optimised version D9I are the preferred cladding and wrapper materials for FBRs to be built in the near future. Optimised versions include specific alloy additions such as phosphorous, silicon and boron to improve resistance to void swelling. Alternate materials with still better resistance to radiation damage are being examined in order to achieve higher burn-up levels. As long-term solution for FBR core structural materials, 9-12\% Cr ferritic-martensitic steels are considered. Data from fuel subassembly performances in fast reactors (Phenix-France, PFR-UK, BN600-Russia) and from the different irradiation experimental programmes confirm the high resistance of ferritic-martensitic steels to swelling and irradiation creep up to a dose of around 200 dpa (Garner \& Gelles 1990; Seran et al 2001). Although these alloys [such as 9Cr-1Mo (EM10), Mod.9Cr-1Mo, 9Cr-2MoVNb (EM12), $12 \mathrm{Cr}-1 \mathrm{MoVW}$ (HT9)] have excellent swelling resistance (1\% swelling reported in HT9 after irradiation at $693 \mathrm{~K}$ for $200 \mathrm{dpa}$ ), their creep resistance decreases drastically above $823 \mathrm{~K}$. Therefore, they are not suitable for clad tubes. A high thermal creep strength is not a primary 
requirement for the wrapper tubes since the operating temperatures are below or at the lower end of the creep range for these materials, and the stresses are low. A reduced creep strength is therefore acceptable. The main issue for this class of materials has been the degradation in impact properties observed for irradiation temperatures lower than $773 \mathrm{~K}$. Consequently, extensive studies involving modification of the composition and initial heat treatments have been carried out to improve the fracture toughness. Significant increase in toughness (i.e. low values of ductile to brittle transition temperature (DBTT), and high values of upper shelf energy) have been realised by (a) avoiding the formation of $\delta$-ferrite and ensuring fully martensitic structure in $9-12 \% \mathrm{Cr}$ steels by close control of nickel and chromium equivalent element concentration ( $\delta$-ferrite regions exhibit greater void formation and swelling than adjacent martensite regions); and (b) optimising the austenitising temperature to refine the prior austenite grain size, and tempering treatments to reduce the strength of the martensite (Dubuisson et al 1993; Klueh \& Harries 2001). Ferritic steels of 9Cr-1Mo grades have been reported to show the lowest increase in DBTT among various ferritic-martensitic steels (Kohyama et al 1996). The decrease in upper-shelf energy and increase in DBTT saturate at high irradiation doses. These materials are, therefore, very promising for wrapper applications and are likely candidates for subsequent cores of PFBR.

\subsection{Non-destructive testing}

Non-destructive testing (NDT) methods have been developed for stringent quality control of fuel cladding tubes (Baldev Raj et al 1994, 1995). The quality of the tubes could be comprehensively assessed using complementary NDT techniques such as ultrasonic (UT) and eddy current (ECT). For the indigenous development of cladding tubes, an advanced eddy current testing methodology has been developed to detect banding (fabrication defect) of tubes, and also defects in the presence of banding, with high sensitivity and reliability. Procedures based on laser scattering technique have been developed to characterise the surface of the tubes. A close correlation between the roughness of outside surface and thickness variation has been established which enabled $100 \%$ assessment of the tubes for detecting unacceptable variations in thickness and surface conditions. As the tube thickness is only 375 microns with close tolerances, it is crucial that all such unacceptable variations are detected. For actual inspection of the tubes, the basis for comparison of the severities of the defects was the defect depths as percentages of the tube wall thickness. Tubes having no defects or defects less than $7 \%$ wall thickness were accepted. The significant percentage of unacceptable tubes after the tubes were tested ultrasonically, underscored the importance and the essential nature of eddy current testing for the pre-service quality control. Random checks by metallography indicated that both ECT and UT are complementary for detection of different types of defects. For example, ECT detected localised dispersion of fine inclusions, while UT successfully detected large inclusions. The outside surface defects could be detected by ECT with high reliability and sensitivity, while the inside defects could be detected by ultrasonic testing. The standard ASTM procedure was followed for ultrasonic testing, and the complete procedure along with suitable probes has been developed at IGCAR for the eddy current testing.

\section{Structural materials}

Austenitic stainless steels are chosen as the major structural materials for the currently operating and planned FBRs all over the world in view of their adequate high temperature mechanical properties, compatibility with liquid sodium coolant, good weldability, availability of 
design data and above all the fairly vast and satisfactory experience in the use of these steels for high temperature service. Irradiation effects are not important for the structural components such as reactor vessel, grid plate, pumps and intermediate heat exchanger. Since the thermal conductivity of austenitic stainless steels is relatively poor, the temperature gradients resulting from start-ups, shut-downs, power transients and other operational changes of the reactor could be quite large in specified locations and under certain operating conditions. This causes low cycle and high strain fatigue damage in the material. Consequently design is dictated by the need to accommodate thermal stresses. On-load periods at elevated temperatures between transients introduce time dependent effects, notably creep and creep-fatigue interaction. Thus, considering the high operating temperature, cyclic and steady loading conditions, and the long service life (40 years), properties like creep, low cycle fatigue (LCF) and creep-fatigue interaction are major considerations in the selection of structural materials and design of components for FBRs.

Sodium streams coming from the core channels are at different temperatures and these, on impinging upon the component surface, produce local variations in the surface temperature with associated stress fluctuations. This phenomenon called thermal stripping leads to high cycle fatigue damage and this is another important consideration for materials chosen for structural components above the core. Materials for the above-core structure applications should also have good resistance to fatigue crack growth. Similar effects occur where the surface level of the sodium coolant oscillates.

With a view to understanding the mechanical behaviour of materials under diverse loading conditions and to evaluate their properties, a number of research programmes have been underway on the materials used in the construction of FBTR and those selected for PFBR. State-of-art research and testing facilities have been set up for studying creep, low cycle fatigue and fracture mechanics properties of materials. Studies on FBTR materials have helped in the generation of a large database on the mechanical properties of these materials, and also to ensure that long term properties assumed in the design of components were fully met. With the development of proper understanding of the mechanical behaviour of FBTR materials, it has been possible to arrive at specifications for PFBR materials, and also to develop these materials within the country in close collaboration with major steel plants.

\subsection{Base metal}

Extensive investigations on the creep properties of three different heats of type 316 stainless steel employed in the construction of FBTR have been carried out over a wide range of test conditions for rupture times as long as 15 years (Mathew et al 1988). Significant heat-toheat variations in the creep rupture properties have been observed in spite of strict control on chemistry, grain size and other processing parameters during manufacturing of the steel. Heat-to-heat variations have been attributed to differences in grain size and amounts of minor elements such as carbon, boron and nitrogen in the different heats of the material. These studies, in addition to providing information on the effects of minor/major elements on creep deformation and fracture, have also generated the useful database needed for assessing the lifetime of reactor components subjected to creep and creep-fatigue loading. On the basis of these studies, nitrogen-alloyed low-carbon austenitic stainless steel types 304 and 316 designated as $304 \mathrm{~L}(\mathrm{~N})$ and $316 \mathrm{~L}(\mathrm{~N}) \mathrm{SS}$ have been selected for the structural components of PFBR.

The composition specifications for $316 \mathrm{~L}(\mathrm{~N})$ and $304 \mathrm{~L}(\mathrm{~N})$ for PFBR are more stringent than the corresponding ASME grades. The composition limits have been revised to meet specific property requirements. Chromium, molybdenum, nickel and carbon contents have 
been specified based on intergranular corrosion resistance criteria developed from light water and fast reactor operating experience. Lower limits for carbon and nitrogen have been specified to ensure mechanical strength equivalent to $316 \mathrm{SS}$ given in the ASME codes. The upper limit of nitrogen is set on considerations of minimising scatter in mechanical properties and easy weldability. Phosphorus, sulphur and silicon are treated as impurities, having adverse effects on weldability. Acceptable maximum limits are hence lowered to values that can be achieved in steel making practice. Considering the adverse effects of titanium, niobium, copper and boron on weldability, acceptable limits have been imposed, though no such limits exist in ASTM specifications. A minimum level has been specified for manganese to improve weldability. A limit has been specified on cobalt to reduce $\mathrm{Co}^{60}$ activity induced by neutron irradiation, to facilitate ease of eventual maintenance. In addition to more stringent composition limits, a specification for inclusions has been added keeping in view that sulphide inclusions are most detrimental especially from welding considerations, and globular oxides are least harmful. For grades $304 \mathrm{~L}(\mathrm{~N})$ and $316 \mathrm{~L}(\mathrm{~N}) \mathrm{SS}$, the grain size number is specified as larger than ASTM No. 2 (i.e., a finer grain size), to achieve optimum high temperature mechanical properties and to permit meaningful ultrasonic examination.

$316 \mathrm{~L}(\mathrm{~N})$ Stainless Steel is used for components experiencing relatively higher temperatures (over $673 \mathrm{~K}$ ) while $304 \mathrm{~L}(\mathrm{~N}) \mathrm{SS}$ has been selected for the rest of the systems. Evaluation of the creep properties of type $316 \mathrm{~L}(\mathrm{~N})$ steel showed that it has generally higher rupture life, lower ductility and lower creep rate as compared to type $316 \mathrm{SS}$ as a result of solid solution strengthening by nitrogen and precipitation strengthening by fine carbides (Mathew et al 1991).

Development of materials for FBR applications requires comprehensive understanding of both the macroscopic deformation behaviour and micromechanisms of creep and fatigue. High temperature Low Cycle Fatigue (LCF) is influenced by a host of time and temperature dependent processes such as creep, oxidation, dynamic strain ageing (DSA) and stress induced precipitation occurring concurrently with cyclic loading, and is therefore a challenging field for investigation. The occurrence of DSA, which involves interaction of solutes with mobile dislocations during high temperature low cycle fatigue in certain range of temperature and strain rate leads to reduction in strain controlled fatigue life (Srinivasan et al 1997, 2000).

It has been recognised that grain size has a significant influence on creep as well as low cycle fatigue deformation and fracture behaviour. The conditions under which grain boundaries contribute to weakening or strengthening of austenitic stainless steels have been identified by a careful investigation of the effects of grain size on tensile, creep and low cycle fatigue properties. Based on these studies, an optimum grain size for improved high temperature creep properties has been established for various stress-temperature conditions (Mannan \& Rodriguez 1984).

During fabrication of components, materials are subjected to cold working to different levels. Cold working has detrimental effects on mechanical properties such as ductility and toughness and on creep resistance depending on time and temperature of exposure. Further, corrosion resistance is also lowered by cold working. Acceptable limits on cold working are therefore required to be determined on fabricated components without resorting to heat treatments. A series of investigations have therefore been carried out to study the influence of cold work on mechanical properties and corrosion behaviour. It is suggested that components manufactured with $316 \mathrm{~L}(\mathrm{~N}) \mathrm{SS}$ be subjected to solution treatments for cold work levels exceeding $15 \%$.

Charpy impact and drop weight testing have been utilised to assess fracture toughness of materials. Ageing induced embrittlement in type 316 stainless steel was characterised using 
both pre-cracked charpy specimens and half-thickness V-notch charpy specimens. A method for determining a toughness parameter akin to the dynamic elastic-plastic fracture toughness parameter $\mathrm{J}_{\mathrm{ld}}$ (except for the specimen size limitation) was established utilizing crack-tip stretch zone measurements (Ray et al 1984; Sreenivasan \& Mannan 2000). It is well-known that the drop-weight testing method can be used to determine the nil-ductility transition temperature $\left(\mathrm{RT}_{\mathrm{NDT}}\right.$ ). A method for directly determining $\mathrm{K}_{l d}$ (dynamic plane strain fracture toughness) at or below the drop-weight nil-ductility temperature from the load-time trace from instrumented drop weight tests has been established (Sreenivasan et al 1992; Moitra et al 1999); the interplay of various experimental factors has been considered for arriving at the most conservative estimate of $\mathrm{K}_{\mathrm{Id}}$.

Hot working is extensively employed for processing austenitic stainless steels into useful shapes. For achieving the required properties, it is essential that the microstructural development during hot working should be carefully controlled and defects and flow instabilities are avoided. For this purpose, it is desirable that the constitutive flow behaviour of the material is adequately characterised in the regimes of temperature and strain rate relevant to hot working and dynamic materials modelling (DMM) processing maps and instability maps are established. In this model, the efficiency of power dissipation through microstructural changes, given by $\eta=2 m /(m+1)$, where $m$ is the strain rate sensitivity, is plotted as a function of temperature and strain rate to obtain a processing map. The different domains exhibited by the map are correlated with specific microstructural processes occurring during hot working. Flow instability occurs during hot deformation if $\xi(\dot{\varepsilon})=\{\partial \ln [m+1)] / \partial \ln \dot{\varepsilon}\} m<0$, where $\dot{\varepsilon}$ is the strain rate. The variation of the instability parameter, $\xi(\dot{\varepsilon}))$ with temperature and strain rate constitutes an instability map, which may be superimposed on the processing map for delineating the regimes of flow instability.

Processing maps and instability maps have been generated for austenitic stainless steels such as type 304L, 316L, 304 and alloy D9, and ferritic steels such as 9Cr-1Mo and mod. 9Cr-1Mo steels on the basis of compression test data in cold, warm and hot working regions (Venugopal et al 1993, 1994, 1996). The safe and unsafe working regions for the above materials have been identified from these maps. These regions have been confirmed through detailed microstructural investigations on deformed samples, analysis of flow behaviour of materials and validation through industrial processes such as rolling, forging and extrusion. The "safe" processing regime predicted by processing maps has been refined using a new methodology based on the values of $m, \dot{m}, s, \dot{s}$ and apparent activation energy during deformation. The optimal processing windows for safe working are given by $0<m \leq 1, m<0, s \geq 1$ and $s<0$, where $s=\partial \log \sigma / \partial(1 / T)$ and $s=\partial s / \partial \log \varepsilon$. The apparent activation energy should be constant in the stable region. The conditions imposed on the parameters ensure stability of deformation and avoid various instabilities such as localised flow, shear bands etc. The modified DMM stability map for 316L SS is shown in figure 4a. The values of activation energy are represented as contours in kilo joules per mole. The grain size of the forged product deformed at $0.15 \mathrm{~s}^{-1}$ is superimposed on the DMM stability map in figure 4b. Figure 4c shows the variation of ultimate tensile strength of the forged product with forging temperature (Rodriguez et al 2000). Grain size and ultimate tensile strength variations are minimal in the stable domain which ensures that the changes in the temperature and strain rate do not affect the product properties significantly.

Austenitic stainless steels are susceptible to intergranular corrosion (IGC), and intergranular stress corrosion cracking (IGSCC) in chloride and caustic environments in the sensitised condition. Theoretical and experimental studies have shown that $(\mathrm{Fe}, \mathrm{Cr})_{23} \mathrm{C}_{6}$ precipitation at grain boundaries and the consequent chromium depletion near grain boundary is the primary 


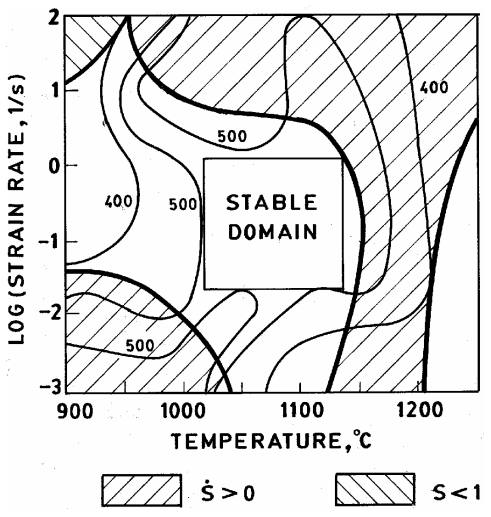

(a)

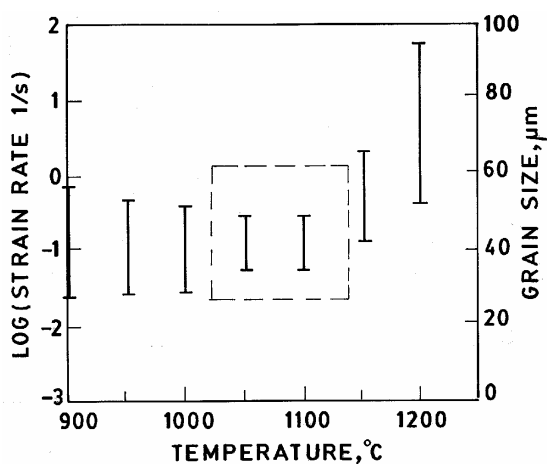

(b)

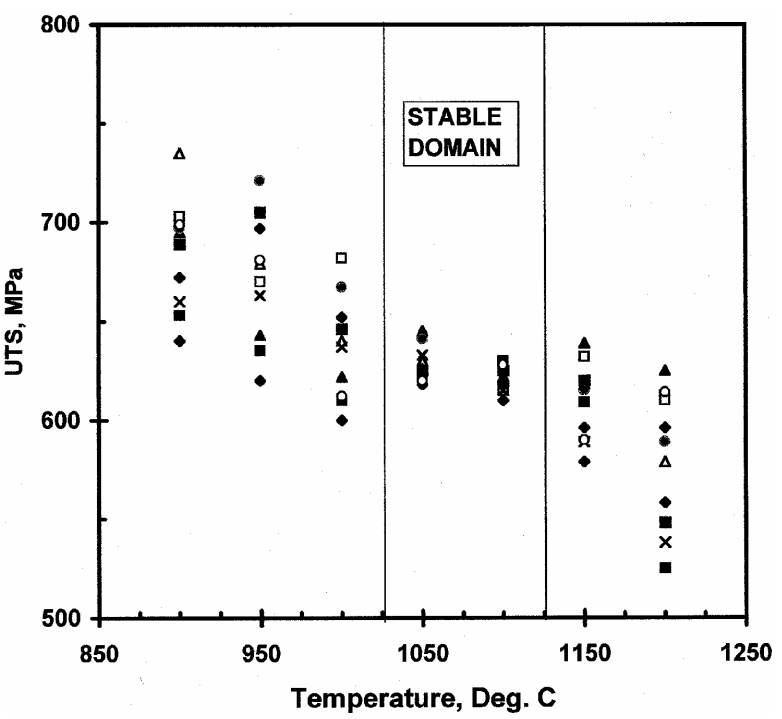

(c)

Figure 4. (a) Dynamic materials model stability map for 316L SS; the values of activation energy are represented as contours in $\mathrm{kJ} / \mathrm{mol}$ and (b) variation of (b) grain size of the forged products deformed at $0.15 \mathrm{~s}^{-1}$ superimposed on the DMM stability map, (c) UTS of the forged product deformed at $0.15 \mathrm{~s}^{-1}$ as a function of forging temperature (Rodriguez etal 2000).

cause of sensitisation. Sensitised stainless steels are susceptible to corrosion due to decrease in chromium concentration in grain boundary regions. In order to predict sensitisation behaviour of $316 \mathrm{~L}(\mathrm{~N}) \mathrm{SS}$ under isothermal and continuous cooling conditions, systematic investigations were carried out, and the time-temperature-sensitisation (TTS) diagrams and continuouscooling-sensitisation (CCS) diagrams have been established. These studies were carried out at various cold work levels also. The TTS diagram is useful to determine the critical linear cooling rate above which there is no risk of sensitisation. The sensitisation behaviour during practical cooling conditions, such as during welding, has been predicted using the CCS diagram (Parvathavarthini et al 1994). It was found that nitrogen addition retards the sensitisation kinetics because nitrogen delays the formation of chromium-rich carbides. The time for the 
onset of sensitisation is a strong function of the temperature. The minimum time required for sensitisation is atleast two orders of magnitude higher in type 316L(N) SS compared to $316 \mathrm{SS}$.

\subsection{Weldability and mechanical properties of welds}

Welding is extensively employed in the fabrication of FBR components. Weld metal cracking and heat affected zone (HAZ) cracking are major areas of concern in welding austenitic stainless steels. Although weld metal cracking can be generally controlled by optimising the chemical composition of the welding consumables, this method cannot control cracking in the HAZ. Weldability of alloy D9 needs evaluation since it is fully austenitic and contains titanium, both of which promote hot cracking. In the case of $316 \mathrm{~L}(\mathrm{~N}) \mathrm{SS}$, the presence of nitrogen could influence cracking.Extensive investigations have been carried out to study hot cracking susceptibilities of $316 \mathrm{~L}(\mathrm{~N})$ and alloy D9 SS in the fusion zone and in the HAZ. In the fusion zone, cracking is found to be a strong function of the solidification mode. Alloy D9 solidifying in the austenitic (A) mode showed much higher cracking susceptibility than the reference 316L SS with a ferritic-austenitic (FA) solidification mode. In alloy D9, it was found that titanium combines with $\mathrm{S}, \mathrm{C}$ and $\mathrm{N}$ to form eutectics that promote cracking in the weld metal and HAZ. Increasing titanium content from 0.2 to $0.4 \%$, increased fusion zone cracking by $20 \%$ and HAZ cracking by several times (Shankar et al 2000). Based on this work, Ti content was optimised to $0.2 \mathrm{wt} \%$ and $\mathrm{Ti} / \mathrm{C}=4$, to reduce cracking susceptibility.

In $316 \mathrm{~L}(\mathrm{~N}) \mathrm{SS}$ weld metal, cracking was not adversely affected by nitrogen in the range of $0.06-0.1 \%$ for the ferritic-austenitic solidification mode ( $\delta$-ferrite in the range 3-7 FN), in comparison to the reference 316L SS. However, in the austenitic-ferritic (AF) or A modes, nitrogen increased cracking when the sulphur level was high (120 ppm) compared to when it was low, $316 \mathrm{~L}(\mathrm{~N}) \mathrm{SS}(<10 \mathrm{ppm} \mathrm{S})$. Nitrogen increased cracking susceptibility in the HAZ irrespective of the level of S, particularly when the ferrite-forming tendency of the underlying base metal was low (Shankar et al 1998). To compare cracking in a fully austenitic structure without nitrogen, nickel added-specimens were also tested. Further studies are being conducted to gain better understanding of the weldability of this class of steels.

The structural integrity of weldments during elevated temperature service has been of serious concern for nuclear components, since a high level of reliability and safety is required and the desired service life is 40 years. Actual plant experience has shown that this concern is well-founded. ASME Boiler and Pressure Vessel Code Section III, Division 1, Subsection $\mathrm{NH}$ which governs the rules for construction of Class I nuclear components for elevated temperature service therefore contains weldment design guidelines based on actual weld metal properties (ASME 2001). Although strength reduction factors for the welds are available, these do not generally take into account (i) stresses built up due to a mismatch in the deformation behaviour of the base and weld metals, and (ii) weakening which occurs in the heat affected zone (Townley 1995). At IGCAR, several studies have been carried out to develop complete understanding of the mechanical behaviour of welds under monotonic and cyclic loading conditions. Creep properties of 316 SS weld metal were found to be inferior to those of the base material with rupture strength of the weld metal being about $20 \%$ lower than that of the base metal; rupture ductility of the weld metal was also lower (Mathew et al 1993). The presence of $\delta$-ferrite in austenitic SS welds influences the mechanical properties, especially at high temperatures where it undergoes phase transformation to carbides and intermetallic phases (Mathew et al 1994). Coarse intermetallic precipitates enhance creep cavitation leading to severe loss of rupture ductility. Addition of nitrogen to the welding consumable 
improves the rupture strength of the weld metal. Nitrogen, apart from providing solid solution strengthening, reduces the diffusivity of chromium in austenitic SS thereby retarding the coarsening of $\mathrm{M}_{23} \mathrm{C}_{6}$ carbides. Therefore, the beneficial effects of nitrogen are retained over longer times.

A comparison of the LCF properties of the base metal, weld metal and weld joint of $316 \mathrm{~L}(\mathrm{~N})$ SS showed that the base metal had the highest fatigue resistance whereas the weld joint showed the lowest fatigue resistance. The inferior fatigue resistance of the weld joint has been ascribed to the presence of coarse grain region in the HAZ of the joint which makes both crack initiation and propagation easier (Nagesha et al 1999; Valsan et al 2000).

Carbides, inclusions and casting pores form during solidification of the weld metal. These act as favourable sites for fatigue crack initiation. Detailed investigations have been performed for assessing the importance of weld discontinuities in strain-controlled LCF behaviour of 308 SS weld metal (Bhanu Sankara Rao et al 1994). Porosity was intentionally introduced by using damp electrodes while slag inclusions were introduced by adopting improper cleaning practice between the weld passes. The presence of porosity and inclusions was found to lower the fatigue life. Porosity on the specimen surface was more harmful and caused a reduction in life by a factor of seven relative to the sound weld metal. Defect combination of porosity and slag inclusions was found to be more deleterious than when these were present alone. Discontinuities acted as crack initiation sites and enhanced crack propagation. These studies are important in the assessment and acceptance of welds containing possible defects.

\subsection{Influence of sodium}

6.3a Corrosion: Austenitic stainless steels have good compatibility with high temperature liquid sodium. However, in a non-isothermal system like the coolant circuit of FBRs, mass transfer of the constituent elements occurs from the high temperature region to the low temperature region. Mass transfer occurs due to dissolution of elements at high temperature and deposition at lower temperature due to decrease in solubility of element with decrease in temperature. Mass transfer is influenced not only by the temperature differential but also by the presense of non-metallic impurities, particularly oxygen, in the sodium. Corrosion is enhanced due to formation of ternary compounds of sodium-transition metal-oxygen. Normally oxygen is controlled to below $2 \mathrm{ppm}$ by cold trapping. Loss of material thickness is estimated to be less than one micron per year at reactor operating temperature of about $823 \mathrm{~K}$. This is determined using the experimental relation reported by Thorley \& Tyyzack (1973) for oxygen content between 2 and $9 \mathrm{ppm}$. In addition to loss of thickness, element transfer results in formation of degraded layer (ferrite + depleted layer). Carbon is an important interstitial element, which is required to impart high temperature strength. However, transport of carbon in the circuit due to difference in carbon activity in steels and sodium, leads to carburization or decarburization. Both have adverse effects on the mechanical properties. Indigenous sodium has a total carbon content of about $25 \mathrm{ppm}$ (elemental and compound form put together), whereas the sodium used in experimental facilities and reactors in other countries is reported to contain carbon less than $1 \mathrm{ppm}$. Studies carried out at IGCAR have shown that total carbon content of $25 \mathrm{ppm}$ is not highly carburising since it is the carbon activity and not the total carbon content, which contributes to mass transport (Rajendran Pillai et al 1998). A dynamic sodium loop made of type 316SS, simulating primary circuit conditions of PFBR with respect to sodium velocity $(5 \mathrm{~m} / \mathrm{s})$ and maximum temperature $(823 \mathrm{~K})$ has been constructed at IGCAR. Based on data obtained for 16000 hours at $823 \mathrm{~K}$, corrosion allowance (loss of thickness + degraded layer) and carbon profiles have been estimated for 40 years of life of PFBR. The data have been utilized in deciding the thickness of intermediate heat exchanger tubes. 
6.3b Mechanical properties: Studies reported so far have shown that there is generally a negligible effect on creep strength and beneficial effect on fatigue strength of austenitic stainless steels when tested in sodium (Lo Torre et al 1984; Yoshida et al 1984). IGCAR is setting-up an in-sodium test (INSOT) facility with a view to creating its own expertise on materials performance for in-sodium service. This would complement the already on-going extensive programmes on mechanical properties, particularly creep and fatigue, of PFBR materials and would help in materials choice, fabrication routes and accurate lifetime predictions for the components operating in liquid sodium. In the meanwhile, studies have been carried out in close collaboration with Forschungzentrum, Karlsruhe, Germany on the creep, fatigue, creep-fatigue interaction and crack growth behaviour of austenitic SS (Mishra et al 1996, 1997). In general, fatigue lives of specimens tested in sodium were higher by a factor of four compared to air environment. However, for tests conducted under hold time conditions, fatigue lives in both the environments were comparable. Thermal exposure to sodium prior to the testing proved to be beneficial to fatigue life since fatigue crack nucleation is delayed by the removal of oxide layer on the surface.

Creep rupture behaviour of base metal and weldments prepared with 16-8-2 filler wire has been investigated at $823 \mathrm{~K}$ (Mishra et al 1996). No adverse environmental effects have been noticed due to sodium on the creep rupture behaviour of these weldments for tests up to 10,000 $\mathrm{h}$. Rupture lives of the weldment were in fact higher in sodium environment than those in air. Rupture lives of the weldments were found to be lower than those of the base metal by a factor of two to five in both air and sodium environments. Rupture strain was usually lower for the weldment than that for the base metal. Sodium exposure did not influence creep and fatigue crack growth rates. Therefore, data obtained in air environment can be conservatively employed for in-sodium service.

6.3c Characterisation and monitoring of sodium: Corrosion and mass transfer in sodium systems are highly dependent on sodium purity. Since the possible sources of impurities in the reactor system are many, the coolant must be continuously monitored using reliable online monitors. Monitoring sodium is also helpful in detecting malfunctions such as steam generator failure, air leak into cover gas, oil leak into sodium etc. Monitors based on electrode concentration cells have been developed at IGCAR for the above purpose (Rajendran Pillai \& Mathews 1986; Periaswami et al 1988); Gnanasekaran et al 1990.

Cesium-137 is the most important radionuclide among fission products from the activity transport point of view as it is released into sodium on fuel-pin failure. Reticulated viterous carbon (RVC) is the most effective trap material for removing Cs-137 from sodium. Cs-137 uptake by RVC from sodium was measured at $433 \mathrm{~K}$. Particle release behaviour of RVC into flowing sodium was measured by simulating the flow conditions in water. Based on these data, a trap design for use in FBTR was formulated.

Chemical characterisation of coolant sodium before charging into the reactor as well as during use is crucial. Analytical methods have been developed for trace metal characterisation of sodium, stainless steels etc. (Mahalingam et al 1982; Vijayalakshmi S et al 1992; Krishna Prabhu et al 1993). A novel laser vaporization technique has been developed (Krishna Prabhu 1993) for introduction of microlitre volumes of samples into an inductively coupled plasma mass spectrometer (ICP-MS) for trace analysis. Also a novel laser vaporisation technique has been developed for the introduction of very small volumes (200 nil) of solutions in ICP-MS. This technique has several advantages over the conventional technique, and is very useful in the analysis of radioactive solutions where it is desirable to keep sample volume low. Sodium 
samples from the primary and secondary loop of FBTR are routinely analysed using these techniques.

\section{Steam generator materials}

Steam generators of FBRs are designed with a single wall separating the water/steam from the sodium. The very high reactivity of sodium with water makes the steam generator one of the most critical components governing the safe and efficient running of the plant. Creep is an important consideration in the selection of steam generator materials. Besides, cyclic loading during start-up, shut-down and power transient operations lead to complex fatigue and creep-fatigue interaction situations. Resistance to decarburisation in liquid sodium and consequent reduction in strength, and resistance to 'wastage' in case of small leaks, as well as resistance to chloride and caustic stress corrosion cracking (SCC), are other important considerations in the choice of materials for steam generator service. Most of the sodiumheated steam generators employ steel $(2.25 \mathrm{Cr}-1 \mathrm{Mo})$ for the evaporator portion. The superheater portions are constructed either from $2.25 \mathrm{Cr}-1 \mathrm{Mo}, 2.25 \mathrm{Cr}-1 \mathrm{Mo}-\mathrm{Nb}$ stabilized steel or from type 304/316/321 austenitic SS. 2.25Cr-1Mo steel is preferred over stainless steel for the evaporator portions because of its resistance to chloride stress-corrosion cracking in aqueous media. As the temperatures are lower in evaporator portion, there is no incentive to use high chromium steels $(9 \mathrm{Cr}-1 \mathrm{Mo}, 9 \mathrm{Cr}-1 \mathrm{Mo}-\mathrm{Nb}-\mathrm{V})$. These considerations favoured the initial choice of $21 / 4 \mathrm{Cr}-1 \mathrm{Mo}$ and $9 \mathrm{Cr}-1 \mathrm{Mo}$ steels as reference materials for evaporator and superheater portions respectively for the PFBR steam generator. In the once-through concept now adopted, mod. $9 \mathrm{Cr}-1 \mathrm{Mo}$ steel (mod. = modified) has been chosen as the PFBR steam generator material. This selection is based on superior high temperature strength of mod. $9 \mathrm{Cr}-1 \mathrm{Mo}$ steel in comparison to $9 \mathrm{Cr}-1 \mathrm{Mo}$ steel. The presence of $\mathrm{Nb}$ and $\mathrm{V}$ in mod. $9 \mathrm{Cr}-1 \mathrm{Mo}$ steel confers better creep resistance than standard $9 \mathrm{Cr}-1 \mathrm{Mo}$ steel. Fine $\mathrm{Nb}(\mathrm{C}, \mathrm{N})$ precipitates that form during processing provide nucleation sites for $\mathrm{M}_{23} \mathrm{C}_{6}$ carbide precipitates. Since with the $\mathrm{V}$ present in the steel, the $\mathrm{M}_{23} \mathrm{C}_{6}$ has $\mathrm{V}$ in addition to $\mathrm{Cr}$, the precipitates remain fine, conferring stability of microstructure and properties. The allowable stresses for the modified alloy are twice that of $2.25 \mathrm{Cr}-1 \mathrm{Mo}$ and $9 \mathrm{Cr}-1 \mathrm{Mo}$ grades at temperatures of $823 \mathrm{~K}$ and above, which enable considerable reduction in wall thickness of steam generator tubes with consequent advantages in terms of improved heat transfer and reduced thermal stresses.

\subsection{Phase evolution diagrams for ferritic steels}

Cr-Mo ferritic steels used in steam generators precipitate different types of carbides, and the evolution of these carbides into a stable phase and its subsequent morphological changes have strong influence on the service performance of these steels. The evolution of secondary phases in Cr-Mo steels at high temperatures has been studied earlier with respect to the type, amount and composition of the precipitates that form at high temperatures. It was seen that the precipitation behaviour was the manifestation of a number of synergistic factors like the differences in the concentration of different solutes, affinity of these solutes to carbon, efficiency of various solutes in scavenging carbon in the matrix and consequent shift in the phase stability of that region. A new concept of phase evolution diagram (PED) depicting the variation of the concentration of carbon in the parent ferrite matrix of the steel as a function of ageing time has been developed for the prediction of microstructural state in ferritic steels (Vijayalakshmi M et al 1999). The phase evolution diagram is constructed by plotting the variation of the concentration of carbon in the $\alpha$-phase with time at a constant 
temperature. Based on the compositions of the different types of carbides and their respective area fractions, the composition of the unprecipitated $\alpha$-matrix was calculated using the mass balance equation. The choice of "variation in carbon concentration" as the basis for PED is justified by the fact that that the primary thermodynamic driving force for the evolution of different metastable states is the relief of supersaturation of carbon in $\alpha$-ferrite. The validity of the extension of this concept to a heterogeneous structure like that in a weldment has been verified based on the calculations of diffusion distances of carbon. PEDs have been generated for the different regions of the weldment, namely weld metal, base metal and heat-affected zone, of $9 \mathrm{Cr}-1 \mathrm{Mo}$ steel at various temperatures and time durations. The carbon contents in the ferrite matrix in the three different regions were calculated. The area fraction, crystallography and the microchemistry of the phases were evaluated in detail using analytical transmission electron microscopy (Vijayalakshmi et al 1999B). It was found that the concentration of carbon in $\alpha$-ferrite decreases with ageing time and reaches a saturation value.

\subsection{Mechanical properties}

In view of their resistance to stress corrosion cracking, ferritic steels are preferred over austenitic stainless steels for steam generator applications. Studies on 2.25Cr-1Mo and $9 \mathrm{Cr}-$ $1 \mathrm{Mo}$ ferritic steels therefore form an important part of the materials development programme at IGCAR. Creep evaluation of 2.25 Cr-1Mo steel base metal, weld metal and weldments has been carried out to assess the relative strengths of different microstructures developed during welding and to arrive at suitable post-weld heat treatments (PWHTs) for optimum mechanical properties of the weldments (Laha et al 1990, 2000, 2001). Weldments (weld joints) always exhibit the lowest creep rupture strength as compared to base and weld metals. The poor creep rupture strength of the weldment results from microstructural degradation in the intercritical region of the heat affected zone. Creep strain distribution studies across the weldment during creep tests clearly establish that the creep strain becomes progressively localised within the intercritical region of $\mathrm{HAZ}$ as the test progresses, indicating that the intercritical structure of $\mathrm{HAZ}$ is the weakest link of the weldment.

9Cr-1Mo steel was initially chosen for the PFBR steam generator. It is a fully martensitic air-hardening material with a good combination of strength and ductility in the normalised and tempered condition. Tensile and creep studies were carried out on normalised (1223 K for $15 \mathrm{~min}$ ) and tempered (1053 K for $120 \mathrm{~min}$ ) base metal, weld metal and weld joints (Laha et al 1999). The weld metal exhibited the highest rupture strength. During the weld thermal cycle, the molten weld metal solidifies as dendrites of austenite and the grain size is much smaller than the prior austenite grain size of normalized base metal. The complete mixing of alloying elements in liquid phase (with the consequent increase in hardenability) as well as higher cooling rate in weld metal than that in the normalized base metal result in much finer martensitic structure in the weld metal than is present in the base metal. Fine structure of the weld metal leads to higher creep strength compared to the base metal. $9 \mathrm{Cr}$-1Mo steel weld joint showed the lowest creep rupture strength. Failure occurred in the intercritical region of HAZ. Poor rupture life of weld joint is attributed to coarser carbides and equiaxed dislocation cell structure in the intercritical region of the HAZ. Following the selection of modified grade of 9Cr-1Mo steel as the PFBR steam generator material, extensive studies have been initiated on tensile and creep properties (Chandravathi et al 2001) Preliminary results indicated that weld joint has the weakest creep strength in mod.9Cr-1Mo steel as well.

Creep-fatigue environment interaction of 2.25Cr-1Mo steel under norrnalised and tempered conditions has been investigated. Low cycle fatigue life-strain range plots exhibit two slope behaviour. These studies advocate caution against extrapolating high strain fatigue data to 
low strain fatigue situations encountered in actual components. Creep and fatigue damage summation diagrams have been prepared for this material. There is uncertainty in designing thick components like tube plate forging with the available information on wrought products which are of relatively thin sections. Detailed investigations have been carried out to evaluate the creep, LCF and creep-fatigue behaviour of $1000 \mathrm{~mm}$ diameter and $300 \mathrm{~mm}$ thick $9 \mathrm{Cr}$ 1Mo tube plate forging (Choudhary et al 1996). LCF resistance of the forging decreases with increasing test temperature $(723-793 \mathrm{~K})$. The reduction in life is attributed to the combined effects of increased inelastic strain and oxidation. Creep and LCF life of the forging were found to be lower compared to those of thin section wrought products and this is attributed to the relatively coarse grain size of the forging. Analysis of hold-time data using linear damage summation approach shows that damage summation of unity could be conservative for this material.

Two main cracking problems commonly encountered during or after welding of ferritic steels are cold cracking, also known as hydrogen-assisted cracking, and stress-relief cracking. Cold cracking is generally avoided by carefully controlling the diffusible hydrogen content in the weld deposit and HAZ microstructure. Stress relief cracking arises due to either segregation of tramp elements on grain boundaries in the HAZ or due to intragranular precipitation. Factors which control the different types of cracking in PFBR materials, i.e. 2.25 Cr-1Mo and $9 \mathrm{Cr}-1$ Mo steels, have been studied.

The integrity of tube to tube sheet weld joints of steam generators of FBRs is critical as the failure of the weld joint may lead to sodium-water reaction and cascade failure of the tube-to-tube sheet welds. Qualification procedures based on microfocal radiography have been developed for detection of defects and cracks of $30 \mu \mathrm{m}$ size within the weld joints. In addition, replication techniques and profilometry of the weld contour are done successfully to ensure the integrity of these joints in severe operating conditions and over long life time.

Transition metal joints (TMJs) between Cr-Mo ferritic steels and austenitic stainless steels used in steam generators are prone to premature failure in service, largely due to thermal cycling associated with start-up and shut-down operations during service. Limited improvement in the service life of these TMJs have been achieved by welding ferritic steel and austenitic SS with Ni-base welding consumables in place of austenitic SS consumables. In order to achieve further improvement in the performance of these joints, a trimetallic TMJ with an intermediate piece of alloy 800 between SS and ferritic steel has been designed. Metallurgical studies have been carried out to characterise and evaluate the TMJ. Based on hot cracking susceptibility, mechanical properties and microstructural studies, 16-8-2 welding consumable has been chosen for welding austenitic SS with Alloy 800 and Inconel 82/182 welding consumable for welding alloy 800 to ferritic steel (Bhaduri et al 1988). It has been estimated that a four-fold increase in the service life can be obtained by using the trimetallic joint in place of the bimetallic joint (Bhaduri et al 1992).

\section{Indigenous development of materials}

\subsection{Plates and forgings}

While most of the materials used in the construction of FBTR were imported, it is important to develop indigenous sources for materials needed for the construction of PFBR in view of the long term programme to construct a series of FBRs during the first half of this century. Materials for the fabrication of major components are required in different product forms like plates, forgings, tubes, rods and hollow bars. Dimensions, grade and tonnage of stainless 
Table 1. Grade, size and tonnage of steels required for PFBR.

\begin{tabular}{|c|c|c|c|c|}
\hline Grade & Product & $\begin{array}{c}\text { Size } \\
\mathrm{W} \times \mathrm{L} \times \mathrm{T}(\mathrm{mm})\end{array}$ & $\begin{array}{l}\text { Quantity } \\
\text { (tonnes) }\end{array}$ & Application \\
\hline $316 \mathrm{~L}(\mathrm{~N})$ & Plate & $\begin{array}{l}2500 \times 4000 \times 1.25-10 \\
2500 / 3000 \times 8000 \times 12-20 \\
2500 / 3000 \times 8000 \times 25-40 \\
2500 / 3000 \times 8000 \times 55-120\end{array}$ & $\begin{array}{l}100 \\
450 \\
325 \\
125\end{array}$ & $\begin{array}{l}\text { Main vessel, inner } \\
\text { vessel, IHX, etc. }\end{array}$ \\
\hline $304 \mathrm{~L}(\mathrm{~N})$ & Plate & $\begin{array}{l}2500 / 3000 \times 8000 \times 3-4 \\
2500 / 3000 \times 8000 \times 6-25 \\
2500 / 3000 \times 8000 \times 25-50\end{array}$ & $\begin{array}{c}300 \\
800 \\
20\end{array}$ & Tanks \\
\hline $\begin{array}{l}304 \mathrm{~L}(\mathrm{~N}) / \\
316 \mathrm{~L}(\mathrm{~N})\end{array}$ & Forgings & $\begin{array}{l}835-2350 \mathrm{~mm} \text { OD } \times 345-1860 \\
\mathrm{ID} \times 100-160 \mathrm{~mm} \text { thick }\end{array}$ & 80 & $\begin{array}{l}\text { Heat exchanger tube } \\
\text { sheet, pumps }\end{array}$ \\
\hline $316 \mathrm{~L}(\mathrm{~N})$ & $\begin{array}{l}\text { Seamless } \\
\text { tubes }\end{array}$ & $19 \mathrm{OD} \times 0.8 \mathrm{~mm} \mathrm{WT} \times 8 \mathrm{~m}$ & 50 & Heat exchangers \\
\hline $\begin{array}{l}304 \mathrm{~L}(\mathrm{~N}) / \\
316 \mathrm{~L}(\mathrm{~N})\end{array}$ & $\begin{array}{l}\text { Seamless } \\
\text { pipes }\end{array}$ & $15-200 \mathrm{~mm}$ nominal size Sch. 40 & 350 & $\begin{array}{l}\text { Sodium and gas } \\
\text { piping }\end{array}$ \\
\hline $316 \mathrm{~L}(\mathrm{~N})$ & $\begin{array}{l}\text { Rounds/ } \\
\text { Hollow } \\
\text { Bars }\end{array}$ & $60-325 \mathrm{~mm}$ diameter $\times 4-5 \mathrm{~m}$ long & 300 & $\begin{array}{l}\text { Control rod drives, } \\
\text { Fuelling machines }\end{array}$ \\
\hline Mod.9Cr- & Plates & $2000 / 3000 \times 5000 \times 12 / 24 \mathrm{~mm}$ & 150 & Steam generator \\
\hline $1 \mathrm{Mo}$ & $\begin{array}{l}\text { Seamless } \\
\text { tubes } \\
\text { Forgings }\end{array}$ & $\begin{array}{l}17.2 \mathrm{OD} \times 2.3 \mathrm{~mm} \mathrm{WT} \times 23 \mathrm{~m} \\
850-1510 \mathrm{OD} \times 375-1185 \mathrm{ID} \times 80- \\
350 \text { thick } \\
1250 \mathrm{OD} \times 260 \text { thick }\end{array}$ & 100 & $\begin{array}{l}\text { Steam generator } \\
\text { Ring flanges } \\
\text { Tubesheet }\end{array}$ \\
\hline
\end{tabular}

steel required in various product forms for the $500 \mathrm{MWe}$ PFBR are listed in table 1 . The close control of chemical composition and very low inclusion contents specified for these materials necessitate the use of special steel making processes like vacuum arc remelting (VAR), vacuum oxygen decarburisation (VOD), argon-oxygen decarburisation (AOD) or similar secondary refining processes. Very stringent non-destructive examinations are also specified in order to detect the presence of flaws which can influence the performance of the components during service. It is now possible to manufacture stainless and low alloy steels of close chemical composition and low inclusion contents within the country. Nitrogen-alloyed type $316 \mathrm{~L}(\mathrm{~N})$ SS plates meeting nuclear specifications have been produced at Alloy Steels Plant (ASP), Durgapur for thicknesses up to $12 \mathrm{~mm}$. This material is currently undergoing evaluation in terms of its mechanical properties, weldability and corrosion behaviour at IGCAR.

However the major difficulty lies not as much in achieving the desired chemistry and quality of the steel but in obtaining plates of large sizes and thicknesses. It was recognised that within the Steel Authority of India (SAIL) family, there are facilities for rolling carbon and low alloy steels to wider $(1400 \mathrm{~mm})$ and longer $(3000 \mathrm{~mm})$ outside the existing facilities at ASP. The possibility of producing stainless steel plates of larger dimensions by combining facilities within SAIL has been explored. In this endeavour, 304L $(\mathrm{N}), 316 \mathrm{~L}(\mathrm{~N})$ and mod. $9 \mathrm{Cr}-$ 1 Mo steel ingots meeting our stringent specifications on chemical composition and inclusion rating would be produced at ASP using the VOD furnace and the ingots would be rolled at Rourkela Steel Plant to plates of dimensions $2000 \times 8000 \times 30 \mathrm{~mm}$. However, modifications in some facilities, like furnaces for heat treatment of the plates and facilities for pickling 
and passivation, would be required. These have been established and plates of dimensions $8 \mathrm{~m} \times 2 \mathrm{~m} \times 30 \mathrm{~mm}$ have been produced in $316 \mathrm{~L}(\mathrm{~N}) \mathrm{SS}$, Mod. $9 \mathrm{Cr}-1 \mathrm{Mo}$ steel and carbon steel.

Apart from plates, large size forgings are also required for PFBR such as the main vessel ring forging of size $8180(\mathrm{OD}) \times 7640$ (ID) $\times 180 \mathrm{~mm}$ thickness in $316 \mathrm{~L}(\mathrm{~N}) \mathrm{SS}$ and tube sheet measuring $1600(\mathrm{OD}) \times 400$ (ID) $\times 150 \mathrm{~mm}$ thickness in mod.9Cr-1Mo steel. It would be possible to produce most of the forgings within the country.

\subsection{Tubes}

Modified 9Cr-1Mo steel tubes of $23 \mathrm{~m}$ length are required for the steam generator. These tubes have been successfully produced by combining facilities at MIDHANI and Nuclear Fuel Complex (NFC). Material meeting our stringent specifications (more stringent than for plates) has been produced at MIDHANI employing secondary refining by electroslag remelting. This material was converted into tubes of $23 \mathrm{~m}$ length at NFC and these have been found to meet all the requirements of NDT.

There are 1758 core subassemblies requiring initially 50,000 fuel clad tubes of $6.6 \mathrm{~mm}$ OD $\times 0.45 \mathrm{~mm}$ wall thickness, $2700 \mathrm{~mm}$ long and 10,000 radial blanket tubes of $14.33 \mathrm{~mm}$ OD $\times 0.6 \mathrm{~mm}$ wall thickness $2400 \mathrm{~mm}$ long with the annual requirement of 10,000 and 3000 respectively in D9 material. Similarly 700 D9 material hexcans of $131.6 \mathrm{~mm}$ across flat (outer) $\times 3.2 \mathrm{~mm}$ wall thickness $\times 3000 \mathrm{~mm}$ length are initially required and 200 annually. These tubes should be of very high quality and must be made by a seamless process and finished in $20 \%$ cold worked condition. Clad tubes and hexcans of alloy D9 material required for PFBR are being produced in a joint programme between IGCAR, Mishra Dhatu Nigam Ltd (MIDHANI) and NFC. About 50 laboratory melts of D9 were produced at IGCAR to optimise melting and casting procedures, forging temperatures and solution annealing treatments. The tensile and creep properties have been assessed as a function of $\mathrm{Ti} / \mathrm{C}$ ratio and cold work. Based on these laboratory studies, commercial heats have been processed at MIDHANI and clad tubes meeting our stringent specifications have been produced. Fabrication of hexcans is under way. It is certain that this joint programme would be able to meet the needs of the entire range of core materials.

\subsection{Welding consumables}

Welding of PFBR components envisages extensive use of manual metal arc (MMA) and tungsten inert gas (TIG) welding processes. Consumables are required to join $316 \mathrm{~L}(\mathrm{~N}) / 304 \mathrm{~L}(\mathrm{~N})$ and mod. 9Cr-1Mo steel, while D9 will be welded without filler metal. Basic flux coated, modified 316 welding electrodes has been developed indigenously. The most critical requirement was the achievement of high toughness at room temperature $\left(3 \mathrm{daJ} \mathrm{cm}{ }^{-2}\right)$ after a $100 \mathrm{~h}$ heat treatment at $1023 \mathrm{~K}$, while still ensuring good slag detachability. Slag detachability becomes a problem with basic fluxes that confer high weld metal toughness. The role of IGCAR in these efforts has been to provide research inputs on flux composition, and testing of deposited weld metal for composition and mechanical properties. Slag detachability has been studied at IGCAR as a function of composition and a software program has been developed to predict detachability. Software has also been developed to predict weld metal composition, given the compositions of the flux and core wire. The mechanical properties achieved by welding electrodes developed indigenously showed that all the properties have been met. Grade 168-2 filler wire required for TIG welding of similar and dissimilar joints involving austenitic stainless steels has been developed indigenously in collaboration with MIDHANI. 
Welding consumables for mod. 9Cr-1Mo steel have to meet a toughness requirement of $45 \mathrm{~J}$ at a test temperature of $293 \mathrm{~K}\left(20^{\circ} \mathrm{C}\right)$ after post-weld heat treatment for $3 \mathrm{~h}$ at $1033 \pm 10 \mathrm{~K}$. Presently, these electrodes are being produced in India using mild steel core wire with all the alloying elements being added through the flux covering, because of the non-availability of core wire of matching composition. Evaluation at IGCAR of one batch of synthetic electrodes supplied by an indigenous manufacturer shows that such electrodes do not meet the RT $\mathrm{NDT}_{\mathrm{N}}$ requirement. (Notch toughness properties are specified with a view to avoid brittle fracture. These properties are nil ductility temperature $\mathrm{T}_{\mathrm{NDT}}$ defined by drop-weight test, and impact energies at various temperatures defined by Charpy V-notch test. The properties from these two tests are considered in combination to define the reference nil ductility temperature $\left(\mathrm{RT}_{\mathrm{NDT}}\right)$ which is useful as an index to define reference lower bound fracture toughnes versus temperature relationship appropriate to brittle-ductile transition region.) The production of mod. 9Cr-1Mo wire rods for welding consumables is therefore a necessity. Efforts are being made to produce special heats of mod. $9 \mathrm{Cr}-1 \mathrm{Mo}$ steel for this purpose, which can then be supplied to the electrode manufacturers.

\subsection{Selection of hardfacing materials}

Nickel-based colmonoy alloys have been selected for replacement of the cobalt-based stellite alloys as the hardfacing material for the nuclear steam supply system (NSSS) components of PFBR. This choice of hardfacing material is aimed at keeping induced radioactivity to the minimum for maintenance and decommissioning purposes. The induced activity computations and the shielding calculations conclusively showed that replacing stellites with colmonoys would result in reduction in the dose rate from most components and the thickness/weight of the lead-handling flasks. As the main concern with the colmonoys is the reduction in their hot-hardness above $723 \mathrm{~K}$, detailed studies were carried out on the effect of long term ageing on the hardness and microstructure of colmonoy hardface deposits on 316L(N) SS (Bhaduri et al 2001). It has been determined that there would be about $30 \%$ reduction in the hardness of comonoy-5 after 40 years of exposure at $823 \mathrm{~K}$. Hardface deposits of Colmonoy would still retain adequate hardness at the end of the components design service-life as the hardness would remain sufficiently higher than the hardness of as-deposited stellites.

\section{Conclusion}

The choice of fuels and materials for FBRs is governed by a combination of a unique set of operating conditions and a major concern for reliability and safety of the components. The fuel should be thermodynamically stable over a wide temperature range. It should have a high melting point, good thermal conductivity and good compatibility with the coolant material, and should be easy to fabricate and reprocess. The presence of substantial concentrations of the fission products alters the chemistry of the irradiated fuel which can promote fuel-clad chemical interactions. The carbide fuel enables a more efficient breeder as compared to the oxide fuel although fuel swelling is a more serious concern than in oxide fuel. Further, the pyrophoric nature of carbide fuel poses serious problems in the fabrication of fuel.

High-temperature mechanical properties such as creep, low cycle fatigue, compatibility with liquid sodium coolant, stress corrosion cracking, void swelling and weldability are some of the important considerations that are to be addressed in the choice of FBR materials. Systematic and exhaustive studies have been carried out to understand these properties in the 
case of materials used in the construction of FBTR and materials selected for PFBR. Special attention has been paid to the study of properties of welds. Development of these materials indigenously through collaboration with other organisations has shown commendable progress. The success of FBRs as an economically viable alternative source of electric power lies in increasing the burn-up of the fuel in order to reduce the fuel cycle cost. Hence, development of materials resistant to radiation damage is of paramount importance. Further, creep, low cycle fatigue, hardfacing, welding and non-destructive evaluation are some of the key areas of research towards the development of reliable components for FBRs.

There are several factors that make indigenisation of fast breeder reactor materials a national imperative, such as self-sufficiency, economic and technological necessity, and availability and utilisation of indigenous capabilities. Experience has shown that identification of critical issues in indigenous production and resolving them through collaborative efforts wherever necessary, have contributed to the success of the programme.

Advanced research and development facilities have been established at IGCAR over the last 25 years in the areas of fuel and materials development. Several groups of scientists and engineers of international competence are working on various problems in collaboration with various educational, research and industrial organisations in the country. These groups have built the necessary scientific and technological expertise to realise the successful introduction of fast breeder reactors in India.

Results reported in this paper are drawn from the research work carried out in various units of IGCAR, and the Radiometallurgy Division at BARC. We gratefully acknowledge the contributions from various colleagues particularly Drs K Bhanu Sankara Rao, S K Ray, H S Khatak, G Periaswamy, M Vijayalakshmi and M/s R Natarajan, P Kalyanasundaram, in the preparation of this manuscript. We are grateful to S B Bhoje, our Director, and Dr. P Rodriguez our (former Director) for their guidance, interest and encouragement.

\section{References}

Adamson M G, Aitken E A, Lindemer T B 1985 Chemical thermodynamics of Cs and Te fission product interactions in irradiated LMFBR mixed-oxide fuel pins. J. Nucl. Mater. 130: 375-392

Ananthasivan K, Kaliappan I, Chandramouli V, Anthonysamy S, Rao P R V, Mathews C K 1993 Carbon potential measurement in the $\mathrm{Mo}-\mathrm{MoC}_{0.47}$ system by methane-hydrogen equilibration. IGCAR Report No. IGC-155

Ananthasivan K, Kaliappan I, Anthonysamy S, Chandramouli V, Rao P R V, Mathews C K, Jacob K T 1996 Gibbs energies of formation of $\mathrm{UMoC}_{1.7}$ and $\mathrm{UMoC}_{2}$. J. Alloys Compounds 245: 40-46

Ananthasivan K, Kaliappan I, Anthonysamy S, Rao P R V, Mathews C K, Jacob K T 1997 Stabilities of ternary carbides $\mathrm{UWC}_{1.75}$ and $\mathrm{UWC}_{2}$. High Temp. Mater. Proc. 16: 255-260

Anthonysamy S, Vasudeva Rao P R, Mathews C K 1986 Carbothermic synthesis of carbides of uranium and plutonium IGC Report No. 82, Indira Gandhi Centre for Atomic Research

Anthonysamy S, Vasudeva Rao P R, Mathews CK 1989 Calculation of vapour presuure in U-Pu-C-O system for optimization of preparation of carbides by carbothermic reduction. Proc. Sundaram Symposium on Thermochemistry and Chemical Processing, Kalpakkam Pp 319-324

Anthonysamy S, Ananthasivan K, Kaliappan I, Chandramouli V, Rao P R V, Mathews C K, Jacob K T 1995 Chemical potential of carbon in the system U-Pu-C-O-N: measurements and calculation. $J$. Nucl. Mater. 223: 20-27 
Anthonysamy S, Ananthasivan K, Kaliappan I, Chandramouli V, Rao P R V, Mathews C K, Jacob K T 1996 Gibbs energies of formation of chromium carbides. Metal Trans. A27: 1919-1924

Antony M P, Daniel C G J, Mathews C K 1997 Studies on the restructuring of fast breeder test reactor fuel by out-of-pile simulation. Nucl. Technol. 117: 299-306

ASME 2001 Boiler and pressure vessel Code, Section III, Division 1, Subsection NH (New York: ASME)

Asuvathraman R, Rajagopalan S, Ananthasivan K, Mathews C K, Mallya 1995 Surface studies on uranium monocarbide using XPS and SIMS. J. Nucl. Mater. 224: 25-30

Baldev Raj, Jayakumar T, Rao B P C 1994 Nondestructive test techniques for assessment of cracks. J. Aeronaut. Soc. India 46: 101-115

Baldev Raj, Jayakumar T, Rao B P C 1995 Nondestructive testing and evaluation of structural integrity. Sādhanā 20: 5-38

Bhaduri A K, Gowrismikar I, Seetharaman V, Venkadesan S, Rodriguez P 1988 Development of transition metal joint for steam generator circuit of prototype fast breeder reactor. Mater. Sci. Technol. 4: 1020-1029

Bhaduri A K, Venkadesan S, Rodriguez P, Mukunda P G 1992 Performance of a trimetallic transition joint. Mater. High Temp. 10: 45-50

Bhaduri A K, Albert S K, Ramasubbu V, Gill T P S, Rao B P S 2001 Effect of long-term ageing on the hardness of Colmonoy-5 hardface deposits. Proc. Int. Welding Conf. (New Delhi: Indian Institute of Welding) pp 737-745

Bhanu Sankara Rao K, Valsan M, Sandhya R, Mannan S L, Rodriguez P 1994 Influence of weld discontinuities on strain controlled fatigue behaviour of 308 stainless steel weld metal. J. Eng. Mater. Technol. 116: 193-199

Bhoje S B 2000 Fast breeder reactor technology. Nuclear India 33: 7-14

Chandravathi K S, Laha K, Bhanu Sankara Rao K, Mannan S L 2001 Microstructure and tensile properties of modified 9Cr-1Mo steel (Grade T 91). Mater. Sci. Technol. 17: 559-565

Chetal S C, Bhoje S B, Govindarajan S, Mannan S L, Paranjpe S R, Rodriguez P, Venkadesan S 1992 Stainless steel applications in prototype fast breeder reactor. Stainless steels - Procesing and metallurgy (eds.) P Krishna Rao, M K Asundi, N B Ballal, S Gadiyar (Omega Sci. Publ.) pp 361-373

Choudhary B K, Bhanu Sankara Rao K, Mannan S L, Kashyap B P 1996 Low cycle fatigue, creep and creep-fatigue behaviour of forged thick section tube plate of $9 \mathrm{Cr}-1 \mathrm{Mo}$ ferritic steel. Proc. Topical Conf on Materials and Nuclear Power, Euromat 96 (London: The Institute of Materials) pp 289-296

Dubuisson P, Gilbon D, Seran J L 1993 Microstructural evolution of ferritic martensitic steels irradiated in the fast breeder reactor Phenix. J. Nucl. Mater. 205: 178-189

Ganguly C, Hegde P V, Jain G C, Basak U, Malhotra R D, Majumdar S, Roy P R 1986 Development and fabrication of $70 \% \mathrm{PuC}-30 \% \mathrm{UC}$ fuel for the fast breeder test reactor in India. Nucl. Technol. 72: 59-69

Garg S P, Goswami G L, Prasad R, Sood D D 1986 Carbon potential of FBTR fuel. Proc. Seminar on Fast Reactor Fuel Cycle (Kalpakkam: IGCAR) vol. 1, pp 61-62

Garner F A, Gelles D S 1990 Neutron induced swelling of commercial alloys at very high exposures. 14th Int. Symp. Effects of radiation on Materials, ASTM STP 1046, 2: 673-683

Gnanasekaran T, Mahendran K H, Sridharan R, Ganesan V, Periaswami G, Mathews C K 1990 An electrochemical hydrogen monitor for measuring dissolved hydrogen in liquid sodium. Nucl. Technol. 90: 408-416

Joseph M, Sivakumar N, Darwin Albert Raj D, Mathews C K 1997 Laser induced mass spectrometric studies on $\mathrm{UO}_{2}$ and graphite. J. Nucl. Mater. 247: 21-27

Joseph M, Sivakumar N 1998 Development of a laser induced vapourization mass spectrometric facility. Inst. Sci. Technol. 26: 81-94

Joseph M, Sivakumar N, Manoravi P 2002 Laser-induced mass spectrometry studies on $\mathrm{UO}_{2}$, UC and $\mathrm{ThO}_{2}$. High Temp. High Pressures (accepted) 
Klueh R L, Harries D R 2001 Dimensional stability - swelling. High chromium ferritic and martensitic steels for nuclear applications, ASTM, Pa, pp 90-103

Kohyama A, Hishinuma A, Gelles D S, Klueh R L, Dietz W, Elrich K 1996 Low-activation ferritic and martensitic steels for fusion applications. J. Nucl. Mater. 231-237: 138-147

Krishna Prabhu R, Vijayalakshmi S, Mahalingam T R, Viswanathan K S, Mathews C K 1993 Laser vapourization inductively coupled plasma mass spectrometry: a technique for the analysis of small volumes of solutions. J. Anal. Atom. Spectrom. 8: 565-569

Krishnaiah M V, Sreenivasan G, Srirama Murthy P, Indira Gandhi Centre for Atomic Research, Kalpakkam (unpublished work)

Laha K, Bhanu Sankara Rao K, Mannan S L 1990 Creep behaviour of post- weld heat-treated 2.25 Cr-1Mo ferritic steel base, weld metal and weldments. Mater. Sci. Eng. A129: 183-195

Laha K, Latha S, Bhanu Sankara Rao K, Mannan S L 1999 Strain rate effects on the low cycle fatigue behavior of type $316 \mathrm{~L}(\mathrm{~N})$ SS base metal and 316 SS weld metal. Proc. Int. Weld. Conf. on Welding \& Allied Technology. Challenges in 21st Century, February, New Delhi, pp 696-703

Laha K, Chandravathi K S, Bhanu Sankara Rao K, Mannan S L, Sastry D H 2000 Prediction of creep deformation and rupture behaviour of 2.25Cr-1Mo weld joint. Int. J. Pressure Vessel Piping 77: 761-769

Laha K, Chandravathi K S, Bhanu Sankara Rao K, Mannan S L, Sastry D H 2001 An assessment of creep deformation and fracture behaviour of 2.25Cr-1Mo similar and dissimilar weld joints. Metall. Mater. Trans, A32: 115-124

Latha S, Mathew M D, Bhanu Sankara Rao K, Mannan S L 2000 Creep deformation behaviour of alloy D9 cladding tubes. Trans. Indian Inst. Metals 53: 249-253

Latha S, Mathew M D, Bhanu Sankara Rao K, Mannan S L 2001 Creep properties of $15 \mathrm{Cr}-15 \mathrm{Ni}$ austenitic stainless steel and the influence of titanium. Creep \& fracture of engineering materials \& structures (ed.) J D Parker (London: The Institute of Materials) pp 507-513

Lo Torre M D C, Solano R P, Melches I, Barosso S, Arroyo J, Borgstedt H U, Schirra M, Frees G 1984 The influence of dynamic sodium on the time to rupture and the creep rate of stainless steel X6 18Cr-11Ni (1.4948). Liquid Metal Eng. Technol.: 467-471

Mahalingam T R, Geetha R, Thiruvengadasami A, Mathews C K 1982 Determination of trace metals in sodium by electrothermal AAS. Anal. Chim. Acta. 142: 189-202

Mannan S L, Rodriguez P 1984 The influence of grain size on creep rupture properties of type 316 SS. Proc 6th Int. Conf. on Fracture (ICF-6) (eds) S R Valluri, D M R Taplin, P Rama Rao (New Delhi: Pergamon) pp 2303-2309

Mathews C K 1993 Thermochemistry of transition metal tellurides of interest in nuclear technology. J. Nucl. Mater. 201: 99-107

Mathew M D, Latha S, Sasikala G, Mannan S L, Rodriguez P 1988 Creep properties of three heats of type 316 SS for elevated temperature nuclear applications. Nucl. Technol. 81: 114-121

Mathew M D, Sasikala G, Rao K B S, Mannan S L 1991 Influence of carbon and nitrogen on the creep properties of type 316 stainless steel at 873K. Mater. Sci. Eng. A148: 253-260

Mathew M D, Sasikala G, Mannan S L, Rodriguez P 1993 A comparative study of the creep rupture properties of type 316 stainless steel base and weld metals. J. Eng. Mater. Technol. 115: $163-170$

Mathew M D, Sasikala G, Mannan S L, Rodriguez P 1994a Effect of stress on the transformation behaviour of Delta-Ferrite in type 316 stainless steel weld metal. J. Mater. Sci. Lett. 13: 194-196

Mathew M D, Sasikala G, Mannan S L, Rodriguez P 1994b Influence of stress on microstructural stability of type 316 stainless steel weld metal. Mater. Sci. Technol. 10: 1104-1108

Mishra M P, Bourgstedt H U, Valsan M, Mannan S L, Rodriguez P 1996 Effect of flowing sodium and prior exposure to sodium on LCF and creep-fatigue interaction behaviour of type $316 \mathrm{~L}(\mathrm{~N})$ stainless steel. Trans. Indian Inst. Met. 49: 497-503

Mishra M P, Mathew M D, Bourgstedt H U, Mannan S L, Rodriguez P 1997 A comparative study of creep rupture behaviour of modified type $316 \mathrm{~L}(\mathrm{~N})$ base metal and $316 \mathrm{~L}(\mathrm{~N}) / 16-8-2$ weldment in air and liquid sodium environments. J. Pressure Vessel Piping 72: 111-118 
Moitra A, Sreenivasan P R, Ray S K, Mannan S L 1999 Determination of dynamic fracture toughness of the heat affected zone of a $9 \mathrm{Cr}-1 \mathrm{Mo}$ steel from instrumented drop-weight tests. Mater. Sci. Technol. 5: 137-143

Nagesha A, Valsan M, Bhanu Sankara Rao K, Mannan S L 1999 Strain controlled fatigue of type $316 \mathrm{~L}(\mathrm{~N})$ base metal and 316SS weld metal at elevated temperatures. Proc. 8th Int. Conf. Fatigue, Fatigue 1999 (eds) Xue-Ren Wu, Z G Wang (Beijing: Higher Education Press) 2: 1303-1308

Parvathavarthini N, Dayal R K, Gnanamoorthy J B 1994 Influence of prior deformation on the sensitisation of AISI type 316 stainless steel. J. Nucl. Mater. 208: 251-258

Periaswami G, Rajan Babu S, Mathews C K 1988 Development of zirconia based oxygen meter for sodium coolant, Paper no. 60. Proc. of 4th Int. Conf. on Liquid Metal Engg and Tech. Avignon, France

Rajendran Pillai S, Mathews C K 1986 An electrochemical meter for measuring carbon activity in liquid sodium. J. Nucl. Mater. 137: 107-114

Rajendran Pillai S, Mathews C K 1987 Carbon potential and carbide equilibrium in 18/8 steels. $J$. Nucl. Mater. 150: 31-41

Rajendran Pillai S, Anthonyswamy S, Prakashan P K, Ranganathan R, Rao P R V, Mathews C K 1989 Carburisation off stainless steel clad by uranium-plutonium carbide fuel. J. Nucl. Mater. 167 : 105-109

Rajendran Pillai S, Khatak H S, Gnanamoorthy J B 1998 Corrosion of AISI type 316 stainless steel and the assessment of long term tensile behaviour. Mater. Trans. Jpn. Inst. Met. 39: 370-377

Ray S K, Sreenivasan P R, Samuel K G, Rodriguez P 1984 Quality control for nuclear grade austenitic stainless steels using charpy impact testing. Proc. 6th Int. Conf. on Fracture (ICF-6) (eds) S R Valluri, D M R Taplin, P Rama Rao (New Delhi: Pergamon) pp 3221-3228

Rodriguez P, Mannan S L, Venugopal S 2000 Optimisation of hot workability and control of microstructure during deformation processing of AISI type 304L stainless steel. Proc. Int. Symp. Thermomechanical Processing of Materials, THERMEC 2000 (in press)

Saha B, Viswanathan R, Sai Baba M, Mathews CK 1988 Thermochemistry and phase relationships in $\mathrm{M}-\mathrm{Te}(\mathrm{M}=\mathrm{Fe}, \mathrm{Cr}$ and $\mathrm{Ni})$ systems of relevance to fuel-clad interactions in fast breeder nuclear reactors - a high-temperature mass spectrometric study. High Temp. High Pressures 20: $47-58$

Sai Baba M, Vanavaramban S, Mathews C K 1987 Effect of oxygen and nitrogen impurities on the thermodynamic properties of uranium-plutonium mixed carbide fuel. J. Nucl. Mater. 144: 56-64

Sai Baba M, Viswanathan R, Mathews C K 1996 Thermodynamic and phase diagram studies on metaltellurium systems employing Knudsen cell mass spectreometry. Rapid Commun. Mass Spectrom. 10: 691-698

Sandhya R, Bhanu Sankara Rao K, Mannan S L 2000 The effect of cold work on the LCF and CFI properties of alloy D6. Trans. Indian Inst. Met. 53: 273-276

Sandhya R, Bhanu Sankara Rao K, Mannan S L 2001 Substructural recovery in cold worked Timodified austenitic stainless steel during high temperature low cycle fatigue. Int. J. Fatigue 23: 789-797

Sengupta A K, Majumdar S, Ganguly C, Purushotham D S C, Roy P R 1986 Determination of some important thermophysical properties of $\left(U_{0.3} P u_{0.7}\right) \mathrm{C}$ fuel. Am. Ceram. Soc. Bull. 65: 1057-1060

Seran J L, Brachet J C, Alamo A 2001 Fast reactor cores, ferritic-martensitic steels for. In Encyclopedia of materials science and technology (London: Elsevier) vol. 3, pp 2865-2867

Shankar V, Gill T P S, Mannan S L, Sundaresan S 1998 Fusion zone and heat affected zone cracking susceptibility of stabilized austenitic stainless steels. Welding J. 77: 193s-201s

Shankar V, Gill T P S, Terrance A L E, Mannan S L, Sundaresan S 2000 Evaluation of hot cracking in nitrogen-bearing and fully austenitic stainless steel weldments. Met. Mater. Trans. A31:3109-3122

Sreenivasan P R, Mannan S L 2000 Dynamic J-R curves and tension-impact properties of AISI 308 stainless steel weld. Int. J. Fracture 101: 229-249 
Sreenivasan P R, Ray S K, Mannan S L, Rodriguez P 1992 Determination of $K_{I d}$ at or below NDTT using instrumented drop-weight testing. Int. J. Fracture 55: 273-283

Srinivasan V, Prabhu R K, Mahalingam T R 1986 Determination of the composition of alloying elements in stainless steel by solution spark technique. IGC Report-80: 1-12

Srinivasan V S, Sandhya R, Valsan M, Bhanu Sankara Rao K, Mannan S L, Sastry D H 1997 The influence of dynamic strain ageing on stress response and strain-life relationship in low cycle fatigue of 316L(N) stainless steel. Scr. Mater. 37: 1593-1598

Srinivasan V S, Valsan M, Sandhya R, Bhanu Sankara Rao K, Mannan S L 2000 Characterization of dynamic strain ageing effects during LCF of type $316 \mathrm{~L}(\mathrm{~N})$ stainless steel. In Materials ageing and life management (eds) Baldev Raj, K Bhanu Sankara Rao, T Jayakumar, R K Dayal (Chennai: Allied Publishers) pp 71-77

Thorley A W, Tyzack C 1973 Processing of liquid metals (London: BNES) p. 257

Townley C H A 1995 High temperature design procedures - developments in Europe since 1986. Proc. 5th Int. Conf. Creep (eds) D A Woodford, C H A Townley, M Ohnami (New York: ASM Int.) pp 1-11

Valsan M, Nagesha A, Kannan R, Bhanu Sankara Rao K, Mannan S L 2000 In Materials ageing and life management (eds) Baldev Raj, K Bhanu Sankara Rao, T Jayakumar, R K Dayal (Chennai: Allied Publishers) p. 93

Vasudevan M, Venkadesan S, Sivaprasad P V 1996a Influence of Ti/(C + 6/7N) ratio on the recrystallization behaviour of a cold worked $15 \mathrm{Cr}-15 \mathrm{Ni}-2.2 \mathrm{Mo}$-Ti modified austenitic stainless steel. $J$. Nucl. Mater. 231: 231-241

Vasudevan M, Venkadesan S, Sivaprasad P V 1996b Influnce of thermomechanical treatments on the microstructural stability of titanium modified austenitic stainless steel. Mater. Sci. Technol. 12: 338-344

Venkadesan S, Sivaprasad P V, Vasudevan M, Rodriguez P 1992 Effect of Ti/C and prior cold work on the tensile properties of $15 \mathrm{Cr}-15 \mathrm{Ni}-2.2 \mathrm{Mo}$-Ti modified austenitic stainless steels. Trans. Indian Inst. Met. 45: 57-68

Venugopal S, Mannan S L, Prasad Y V R K 1993 Criteria for prediction of flow in stabilities and microstructural manifestations during warm working of AISI 304L stainless steel. Mater. Sci. Technol. 9: 1021-1030

Venugopal S, Mannan S L, Prasad Y V R K 1994 Processing maps for hot working of commercial grade wrought stainless steel type AISI 304. Mater. Sci. Eng. A177: 143-149

Venugopal S, Vasudevan M, Sridhar Venugopal, Sivaprasad P V, Jha S K, Pandey P, Mannan S L, Prasad Y V R K 1996 Industrial validation of processing maps of 316L stainless steel using hot forging, rolling and extrusion. Mater. Sci. Technol. 12: 955-962

Vijayalakshmi M, Saroja S, Raghunathan V S 1999a Validity of concept of phase evolution diagram to weldments of 9Cr-1Mo steel. Scri. Mater. 41: 149-152

Vijayalakshmi M, Saroja S, Mythili R, Thomas Paul V, Raghunathan V S 1999b Microstructural zones in the primary solidification structure of weldment of $9 \mathrm{Cr}-1 \mathrm{Mo}$ steel. Met. Metall. Trans. A30: $161-174$

Vijayalakshmi S, Krishna Prabhu R, Mahalingam T R, Mathews C K 1992a Application of ICP-MS in trace metal characterization of nuclear materials. Atom. Spectrosc. 13: 61-65

Vijayalakshmi S, Krishna Prabhu R, Mahalingam T R, Mathews C K 1992b Determination of trace metals in uranium oxide by ICPMS combined with on-line solvent extraction. J. Anal. Atom. Spectrom. 7: 565-569

Viswanathan R, Sai Baba M, Darwin Albert Raj D, Balasubramanian R, Saha B, Mathews C K 1989 Thermochemistry of metal-rich chromium telluride and its role in fuel-clad chemical interaction. J. Nucl. Mater. 167: 94-104

Yoshida E, Funada T, Emo M I, Nakayarn K, Nihei I, Yoshitoshi Y 1984 Creep-rupture properties of the nuclear fuel cladding tube for the fast breeder reactor in high temperature sodium. Liquid metal engineering and technology (London: BNES) pp 463-466 